\title{
Cross-sectional study of the relationships among bedding materials, bedding bacteria counts, and intramammary infection in late-lactation dairy cows
}

\author{
S. M. Rowe, ${ }^{1 *} \odot$ S. M. Godden, ${ }^{1} \odot$ E. Royster, ${ }^{1} \oplus$ J. Timmerman, ${ }^{1}$ B. A. Crooker, ${ }^{2} \odot$ and M. Boyle ${ }^{3}$ \\ ${ }^{1}$ Department of Veterinary Population Medicine, University of Minnesota, St. Paul 55108 \\ ${ }^{2}$ Department of Animal Science, University of Minnesota, St. Paul 55108 \\ ${ }^{3}$ Zoetis, Hager City, WI 54014
}

\section{ABSTRACT}

Objectives of this study were to (1) describe the intramammary infection (IMI) prevalence and pathogen profiles in quarters of cows approaching dry-off in US dairy herds, (2) compare IMI prevalence in quarters of cows exposed to different bedding material types, and (3) identify associations between bedding bacteria count and IMI in cows approaching dry-off. Eighty herds using 1 of 4 common bedding materials (manure solids, organic non-manure, new sand, and recycled sand) were recruited in a multi-site cross-sectional study. Each herd was visited twice for sampling. At each visit, aseptic quarter-milk samples were collected from 20 cows approaching dry-off (>180 d pregnant). Samples of unused and used bedding were also collected. Aerobic culture was used to determine the IMI status of 10,448 quarters and to enumerate counts $\left(\log _{10}\right.$ $\mathrm{cfu} / \mathrm{mL}$ ) of all bacteria, Staphylococcus spp., Streptococcus spp. and Streptococcus-like organisms (SSLO), coliforms, Klebsiella spp., noncoliform gram-negatives, Bacillus spp., and Prototheca spp. in unused $(\mathrm{n}=148)$ and used $(\mathrm{n}=150)$ bedding. The association between bedding bacteria count and IMI was determined using multivariable logistic regression with mixed effects. Quarter-level prevalence of IMI was $21.1 \%$, which was primarily caused by non-aureus Staphylococcus spp. $(11.4 \%)$ and SSLO (5.6\%). Only modest differences in IMI prevalence were observed between the 4 common bedding material types. Counts of all bacteria in unused bedding was positively associated with odds of IMI caused by any pathogen [ALL-IMI; odds ratio (OR) $=1.08]$. A positive association was also observed for counts of SSLO in unused bedding and SSLO-IMI (OR $=1.09$ ). These patterns of association were generally consistent across the 4 common bedding materials. In contrast, the association between counts of all bacteria

Received June 6, 2019.

Accepted July 29, 2019.

*Corresponding author: samrowe101@gmail.com in used bedding and ALL-IMI varied by bedding type, with positive associations observed in quarters exposed to manure solids $(\mathrm{OR}=2.29)$ and organic non-manure $(\mathrm{OR}=1.51)$ and a negative association in quarters exposed to new sand $(\mathrm{OR}=0.47)$. Findings from this study suggest that quarter-level IMI prevalence in latelactation cows is low in US dairy herds. Furthermore, bedding material type may not be an important risk factor for IMI in late lactation. Higher levels of bacteria in bedding may increase IMI prevalence at dry-off in general, but this relationship is likely to vary according to bedding material type.

Key words: intramammary infection, mastitis, dry cow therapy, bedding, manure solids

\section{INTRODUCTION}

Cows acquire IMI during lactation, some of which can persist through the dry period to affect udder health in subsequent lactations (Green et al., 2002). To cure these IMI, intramammary antimicrobial treatments are administered to cows at the time of dry-off (dry cow therapy; DCT). However, there is interest within the dairy industry to reduce antimicrobial use, and DCT is a substantial contributor to antimicrobial use on dairy farms (Pol and Ruegg, 2007; Redding et al., 2019). Antimicrobial use could be reduced by employing more efficient DCT strategies (such as selective DCT) and by reducing the acquisition of new IMI during lactation, thereby reducing the proportion of cows requiring antimicrobial treatment at dry-off. However, the absence of a nationwide survey of IMI at dry-off in the United States impedes the development and widespread adoption of more efficient DCT programs. Furthermore, additional research is needed to determine risk factors for IMI at dry-off. Molecular epidemiologic studies have identified IMI-causing strains of bacteria in bedding material, suggesting that bedding can act as a reservoir for some pathogens (Verbist et al., 2011; Eraclio et al., 2019), and aerobic culture of bedding to determine bedding bacteria count (BBC) has been used to ap- 
proximate bedding-associated mastitis risk (Hogan et al., 1989). However, few studies have demonstrated a clear association between $\mathrm{BBC}$ and udder health, and none have evaluated the association between BBC and IMI in late-lactation cows. Hogan et al. (1989) reported a positive association between counts of gram-negative bacteria and Klebsiella spp. in bedding and clinical mastitis incidence in 9 US dairy herds. However, no associations were found with other pathogens, including environmental Streptococcus spp., which were a common cause of clinical mastitis in that study. Thomas et al. (1983) identified a positive association between $\mathrm{BBC}$ and clinical mastitis incidence for Klebsiella spp. but not Escherichia coli. Similarly, a longitudinal study of herds using manure solids bedding found that when Klebsiella spp. counts exceeded $6.0 \log _{10} \mathrm{cfu} / \mathrm{g}$, the proportion of clinical cases caused by Klebsiella spp. increased (Carroll and Jasper, 1978). Natzke and LeClair (1976) failed to increase the incidence of new IMI in a small sample of cows, after inoculating their sawdust bedding with $E$. coli for 4 wk.

Indirect evidence suggests that high levels of bacteria in bedding can negatively affect udder health. Many studies have demonstrated a correlation between BBC and teat end bacteria count (Hogan and Smith, 1997; Hogan et al., 1999; Zdanowicz et al., 2004; Proietto et al., 2013; Rowbotham and Ruegg, 2016b). Extrapolating these associations to udder health is problematic because no studies to our knowledge have demonstrated a strong association between teat end bacteria counts and mastitis. Consequently, there is currently a lack of rigorous evidence to support the widely held belief that high $\mathrm{BBC}$ is a risk factor for IMI and mastitis. Demonstrating an association between BBC and IMI would help to validate $\mathrm{BBC}$ as a diagnostic or monitoring tool, and increase the relevance of studies that have investigated methods to reduce BBC (Hogan and Smith, 1997; Hogan et al., 1999; Godden et al., 2008; Bey et al., 2009; Rowbotham and Ruegg, 2016b).

In addition, bedding-related research is needed to address pragmatic questions facing dairy producers. Producers in confinement-managed herds need to know the advantages and disadvantages of different bedding material systems, especially with regard to the commonly used bedding materials: manure solids (RMS), new sand (NSA), recycled sand (RSA), and organic non-manure $(\mathbf{O N})$ bedding. It is generally expected that farms using bedding material types with higher $\mathrm{BBC}$, such as RMS, may have a higher prevalence of IMI or a different profile of pathogens causing IMI. Furthermore, certain bedding material types may exhibit synergism with BBC in the development of IMI. These hypotheses are based on findings from observational studies where bedding bacterial populations and udder health outcomes varied according to bedding material type (Hogan et al., 1989; Zdanowicz et al., 2004; Bey et al., 2009; Rowbotham and Ruegg, 2015, 2016a,b). For example, a prospective cohort study reported by Rowbotham and Ruegg (2016b) found that NSA bedding had the lowest counts of Streptococcus and Streptococcus-like organisms (SSLO), gram-negative, and coliform bacteria when compared with RSA and RMS. In the same study, primiparous cows exposed to NSA had significantly lower teat end coliform counts and a tendency for a lower incidence rate of clinical mastitis than cows exposed to other bedding materials (Rowbotham and Ruegg, 2016a). A cross-sectional study of 325 Wisconsin dairy herds by the same research group also found that herds using sand bedding had lower SCC and higher milk production than herds using organic bedding materials (Rowbotham and Ruegg, 2015). In summary, more research is needed to understand the prevalence of, and bedding-related risk factors for IMI in cows approaching dry-off. Improving our knowledge in this area could lead to improvements in bedding management, reductions in IMI, and more efficient approaches to DCT.

The objectives of this study were to (1) describe the IMI prevalence and pathogen profiles in quarters of cows approaching dry-off in US dairy herds, (2) compare IMI prevalence in quarters of cows exposed to different bedding material types, and (3) identify associations between BBC and IMI in cows approaching dry-off.

\section{MATERIALS AND METHODS}

The Strengthening the Reporting of Observational Studies in Epidemiology-Veterinary Extension (STROBE-Vet) statement guidelines were followed in the reporting of this study (Sargeant et al., 2016). A cross-sectional study of US dairy herds was conducted between August 2017 and April 2018.

\section{Study Herds}

A convenience sample of 80 herds from 10 dairy states was selected. Herd eligibility criteria included milking herd size greater than 200 cows, having a working relationship with the University of Minnesota or a local Zoetis Quality Milk Specialist $(\mathrm{n}=9)$, and be using 1 of 4 bedding materials: RMS, NSA, ON, or RSA. In July 2017, a list of eligible herds $(n=152)$ was created and 80 were selected using a randomized, stratified sampling method in an attempt to enroll an equal number of herds using each bedding type and 
to maximize the representation of each bedding type within US dairy regions (Northeast, Midwest, Northwest, and Southwest).

\section{Farm Visits for Sample and Data Collection}

Each farm was visited once during summer (August to September 2017) and once during winter (December 2017 to April 2018). At each visit, aseptic quarter milk samples were collected from 20 late-gestation cows ( $>180$ d pregnant), as well as used and unused bedding from the pens of sampled cows. Farms located in Minnesota $(\mathrm{n}=10)$ were visited by the authors and veterinary students from the University of Minnesota. All remaining farms $(\mathrm{n}=70)$ were visited by Zoetis Quality Milk Specialists. At each visit, study personnel followed a standardized sample collection protocol. Cow eligibility criteria for selection included the following: lactating, managed in the same bedding environment for the past $100 \mathrm{~d}$, greater than $180 \mathrm{~d}$ pregnant, and not in the hospital pen on the day of visit. After creating a list of all eligible primiparous and multiparous cows, up to 20 cows were selected, with a view to enrolling $40 \%$ primiparous and $60 \%$ multiparous cows, respectively. Duplicate, aseptic milk samples were collected from each functional quarter of enrolled cows according to NMC guidelines (NMC, 2017). Briefly, after milking staff performed their usual pre-milking teat disinfection routine, investigators, wearing clean disposable gloves, scrubbed teat ends with $70 \%$ isopropyl alcohol-soaked gauze swabs, discarded 3 squirts of foremilk, and sampled approximately 20 to $30 \mathrm{~mL}$ of milk into sterile $60-\mathrm{mL}$ vials. Samples were immediately chilled on ice.

For sampling of unused bedding material, investigators collected 20 handfuls from various sections of the pile into a disinfected bucket. Bedding in the bucket was then thoroughly mixed and a subsample (approximately $1 \mathrm{~L}$ ) was transferred into a resealable plastic bag, air expressed, and then sealed. In dry-lot herds ( $\mathrm{n}=2)$, no unused bedding was collected, and used bedding was collected from the pens of enrolled latelactation cows, in the same manner as described above. In freestall herds, one handful of used bedding was collected from the top $5 \mathrm{~cm}$ of material in the back third of at least 20 stalls in the late-lactation pen. Care was taken to avoid obvious manure pats when sampling. A subsample was collected into a plastic bag from the bucket, in the same way described for unused bedding. The bucket was disinfected between the sampling of used and unused bedding, and investigators used new gloves before handling bedding material. Bedding and milk samples were immediately chilled and stored at $-20^{\circ} \mathrm{C}$ at the study site before being freighted overnight on ice to the Laboratory for Udder Health (LUH) at the Veterinary Diagnostic Laboratory, University of Minnesota (St. Paul). Samples were stored at the LUH at $-20^{\circ} \mathrm{C}$ and processed within $8 \mathrm{wk}$ of collection. At each visit, study investigators completed a questionnaire with the farm manager or owner to obtain information about bedding management practices, parlor routines, and herd demographics.

\section{Microbiological Culture of Milk and Bedding Samples}

Milk Culture. The IMI status of each quarter was determined using standard microbiologic methods. Milk samples were thawed at room temperature, homogenized by gentle inversion, and plated onto Columbia CNA agar with 5\% sheep blood (CNA) and MacConkey agar. Agar plates were inoculated with one loop-full (approximately $10 \mu \mathrm{L}$ ) of sample using disposable plastic loops and incubated in aerobic conditions and at 37 $\pm 2^{\circ} \mathrm{C}$ for 42 to $48 \mathrm{~h}$. Only one sample from each quarter was cultured unless this first sample was contaminated. Samples were classified as contaminated if more than 2 isolates were recovered. Isolates were identified using a MALDI-TOF mass spectrometer (Microflex; Bruker Daltonics Inc., Billerica, MA). Peaks produced by each isolate were analyzed by the MALDI-TOF Biotyper reference library. The confidence level for each diagnosis reported by the software was used in the following fashion: $>2.0$, species level diagnosis recorded; $1.8-2$, genus level diagnosis recorded; and $<1.8$, MALDI-TOF diagnosis not recorded and traditional identification methods used. Diagnoses obtained using MALDI-TOF were further evaluated by comparing peaks to a database of commonly isolated mastitis pathogens that have been internally validated at the LUH using $16 \mathrm{~S}$ sequencing. Traditional identification methods included differential growth on selective media, colony morphology, catalase reaction, Gram stain, and cytology. To improve the specificity of IMI classification (i.e., reduce false positives), non-aureus Staphylococcus spp. (NAS) isolates with less than 2 colonies $(<200 \mathrm{cfu} / \mathrm{mL})$, and Bacillus spp. isolates with less than 5 colonies $(<500$ $\mathrm{cfu} / \mathrm{mL}$ ) were reclassified as "no growth" and the quarter considered uninfected (Dohoo et al., 2011). This adjustment was made because poor specificity is a more potent source of biased measures of association than poor sensitivity (Haine et al., 2018).

Bedding Bacteria Count. Bedding samples were thawed at room temperature before a $50-\mathrm{mL}$ sub-sample was weighed and transferred to a sterile plastic bag (Whirl-Pak, Nasco, Fork Atkinson, WI) along with 250 $\mathrm{mL}$ of sterile water to create a 1:5 dilution. After the bedding-water mixture was allowed to stand at room temperature for $10 \mathrm{~min}$, the bag was agitated, and 
$200 \mu \mathrm{L}$ of 4 dilutions $(1: 5,1: 50,1: 500$, and 1:5,000) of the resulting bedding suspension were inoculated onto CNA and MacConkey agars as a lawn. Cultures were incubated in aerobic conditions at $37 \pm 2^{\circ} \mathrm{C}$ for 42 to 48 $\mathrm{h}$ before reading. At reading, bacteria groups were identified using visual inspection by an experienced microbiologist and enumerated from the dilution plate with the optimal number of colonies (25 to 250 per plate) as being Bacillus spp., Staphylococcus spp., SSLO, coliforms, Klebsiella spp. noncoliform gram-negatives, or Prototheca spp. We used MALDI-TOF to confirm the identity of representative colonies. The counts from each bacteria group were summed to determine total bacteria count. Colony forming units per milliliter of bedding, per gram of wet bedding, and per gram of dry bedding were recorded. Dry matter percentage was determined by drying duplicate $2-\mathrm{g}$ sub-samples at $100^{\circ} \mathrm{C}$ for $24 \mathrm{~h}$.

\section{Statistical Analysis}

Sample Size Calculation. Sample size calculations were performed using herd-level measures of IMI prevalence (i.e., percentage of quarters infected per herd); however, analysis was eventually conducted using a quarter-level outcome (infected: yes/no). We estimated that 20 herds per bedding material type were necessary to detect a 5 percentage point difference in prevalence of gram-negative IMI between any 2 bedding types (e.g., RMS vs. NSA). The following assumptions were used in the sample size calculation: $\alpha=0.05$, power $=$ $80 \%$, prevalences of 0.05 and 0.10 in reference and comparison herds, standard deviation of IMI prevalence $=$ 0.028. The calculated sample size was further inflated to account for multiple comparisons and the exclusion of ineligible herds and quarters.

Variable Management. Herd demographic information, bedding management practices and laboratory findings were recorded in spreadsheets (Google Sheets, Mountain View, CA, and Microsoft Excel, Redmond, WA) and imported into the R Statistical Programming Environment (R Core Team, 2018) for analysis. Quarters without a determined bacteriological status, mostly due to contamination of milk samples, were excluded from analysis. Normality of continuous variables was assessed by visualizing normal quantile-quantile plots. For analysis, BBC values greater that zero were $\log _{10}$ transformed, whereas zero counts received a value of $\log _{10}(0.5 \times$ the detection limit of the test $)$ or $1.1 \log _{10}$ cfu per mL. Assigning values of $0.5 \times$ the detection limit, although somewhat arbitrary, can reduce bias associated with limitations in diagnostic tests (Lubin et al., 2004). Region was dichotomized into east (Indiana, Michigan, Minnesota, New York, Wisconsin) and west
(California, Idaho, Oregon, Texas, Washington), which is consistent with other surveys of US dairy farms (NAHMS, 2014). Correlations between explanatory variables were determined using Pearson correlation coefficient and Kendall's tau for normally and nonnormally distributed continuous variables, respectively. Highly correlated variables $(>0.7)$ were not offered to the same model, with the more suitable variable chosen based on missing values, reliability of measurement, or biological plausibility.

Association Between Bedding Bacteria Count and Intramammary Infection. A directed acyclic graph illustrates the general model building approach used for this objective (Figure 1). Multivariable logistic regression models with mixed effects were used to determine associations between $\mathrm{BBC}$ and odds of quarter-level IMI using the "glmer" function, with the "bobyqa" optimizer, in the "Ime4" package. The 3 outcome variables of interest included ALL-IMI, NAS-IMI, and SSLO-IMI. The ALL-IMI cases were defined as quarters infected with at least one pathogen. The NAS-IMI cases were defined as quarters infected with any Staphylococcus spp. other than Staphylococcus aureus, with all remaining quarters classified as a noncase. The SSLO-IMI cases included quarters infected with Aerococcus, Enterococcus, Lactococcus, and Streptococcus species, with all remaining quarters classified as non-cases. We also attempted to develop models to describe associations between BBC and IMI caused by coliforms, but these were abandoned because (1) the prevalence of coliform IMI was very low and thus associations were unlikely to be of biological significance, and (2) multivariable models failed to converge, possibly due to a small number of cases.

For each of the 3 IMI outcomes, the corresponding $\mathrm{BBC}$ measure was used as the primary explanatory variable of interest. For the ALL-IMI models, $\log _{10} \mathrm{cfu} /$ $\mathrm{mL}$ of total bacteria count per $\mathrm{mL}$ of bedding was used. For the NAS-IMI and SSLO-IMI models, $\log _{10} \mathrm{cfu} / \mathrm{mL}$ of Staphylococcus spp. and SSLO counts were used, respectively. For comparison, equivalent models that included BBC measures in alternative units $(\mathrm{cfu} / \mathrm{g}$ and $\mathrm{cfu} / \mathrm{g}$ of DM) were also created. In these models, the $\mathrm{BBC}$ measure was included as a continuous variable. As an exploratory analysis, additional models were developed using various categorical $\mathrm{BBC}$ variables that were created by collapsing $\mathrm{BBC}$ into 2, 3, or 4 levels based on percentiles. For example, BBC was dichotomized at the 60 th percentile, to create a high and low group. The hierarchical structure of the data was addressed in all models by fitting random intercepts for cow and herd, such that quarters were nested within cows, and cows within herds. Other explanatory variables were offered in multivariable models to account for confounding, 
and to identify independent predictors of the outcome of interest. Potential cow-level covariates included days pregnant, parity (grouped into 4 categories: 1, 2, 3, $\geq 4$ ), and breed (Holstein or non-Holstein). The remaining potential covariates were measured at the herd level, including season, region, herd average daily milk production $(\mathrm{kg} / \mathrm{cow}$ per day), bedding material type, frequency of bedding replacement, herd size, paddock access, milking schedule, unit washing practices, use of forestripping, use of udder clipping, and use of tail hair management (e.g., docking or trimming switches). Bedding type was expected to be a confounder of the association between BBC and IMI and, thus, was forced into all models that included multiple bedding types as a fixed effect. Other potential covariates were initially evaluated using univariable logistic regression with mixed effects, with those associated (type 2 Wald chi-squared test at $P<0.2$ ) with the outcome of interest being offered to the multivariable model in the first step. The covariates with the highest $P$-values were removed, one at a time from the model in successive steps, until all remaining fixed effects had type 2 Wald chi-squared tests at $P<0.05$. Bedding bacteria count was forced into the final model, regardless of $P$-value. Biologically plausible 2-way interactions on the multiplicative scale were investigated and retained in the model if the Wald test for the interaction was $P<0.05$. Model fit was assessed by comparing regression curves (produced with estimated marginal means) to the raw prevalence of IMI at various values of BBC using a smoother.

Associations Among Bedding Type, Season, and Intramammary Infection. Prevalences of IMI at the quarter and herd level were calculated. Models were built using the same methods described earlier to determine associations between the explanatory variables bedding material type and season and the outcome variables ALL-IMI, NAS-IMI, and SSLO-IMI.

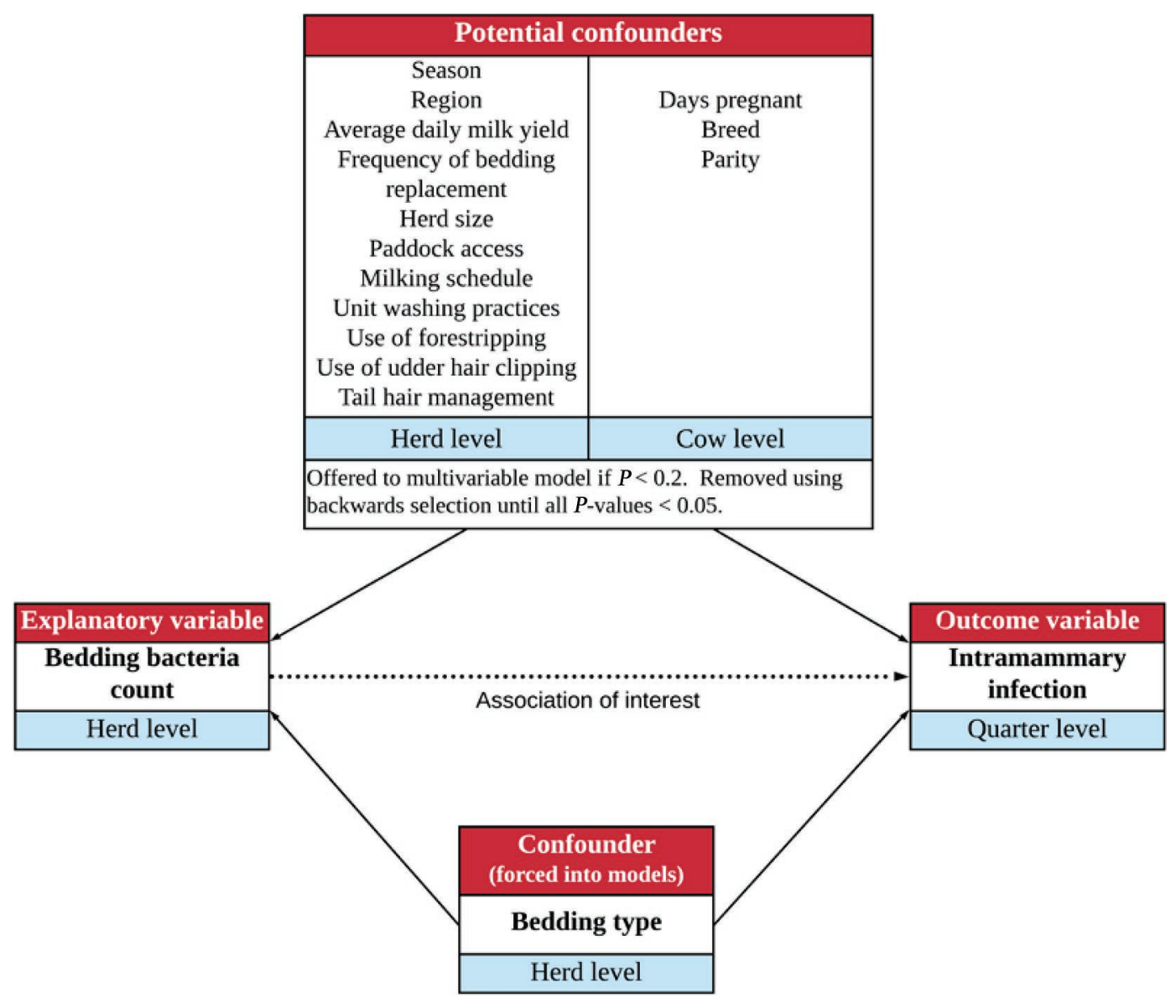

Figure 1. Directed acyclic graph illustrating the hypothesized causal relationship between bedding bacteria count and IMI and the model building strategy used to control for variables hypothesized to confound this relationship. The hierarchical structure of the data set is outlined by describing the measurement level of each variable in blue boxes (i.e., quarter level, cow level, or herd level). Random effects terms for cow and herd were used to account for clustering, and confounders were included into multivariable models to adjust for confounding. 
Only crude prevalences are reported in this study and all odds ratio (OR) estimates are derived from multivariable models (i.e., they are adjusted for covariates).

\section{RESULTS}

\section{Enrollment}

Herds were enrolled from the following states: California $(\mathrm{n}=16)$, Idaho $(\mathrm{n}=6)$, Indiana $(\mathrm{n}=4)$, Michigan $(\mathrm{n}=5)$, Minnesota $(\mathrm{n}=10)$, New York $(\mathrm{n}=9)$, Oregon $(\mathrm{n}=1)$, Texas $(\mathrm{n}=2)$, Washington $(\mathrm{n}=6)$, and Wisconsin $(\mathrm{n}=21)$. The median number of milking cows per herd was 1,820 (235 to 9,650 ), and the average daily milk production was 38 (23 to 48 ) $\mathrm{kg}$ per cow. Enrolled cows were either Holstein $(\mathrm{n}=2,678 ; 85 \%)$ or other ( $\mathrm{n}=480 ; 15 \%)$, which included Holstein-cross, Jersey, Brown-Swiss, and their crosses. Housing systems used for lactating cows included freestall $(\mathrm{n}=73 ; 91 \%)$, dry lot $(\mathrm{n}=2 ; 3 \%)$, and combinations of either freestall and dry lot $(\mathrm{n}=4 ; 5 \%)$, or freestall and bedded back ( $\mathrm{n}$ $=1 ; 1 \%)$. In herds with combination bedding systems, only cows using freestalls were enrolled.

A total of 12,345 quarters from 3,158 cows from 80 herds were initially selected into the study. Of these, 785 quarter samples collected at 10 farm visits, from 8 herds, were excluded from analysis either because of a recent change in bedding material type $(<100 \mathrm{~d})$, or because the herd was using a bedding material type that did not meet the inclusion criteria. One herd changed bedding system between visits, but was retained in the study because each visit met inclusion criteria. A further $9.6 \%(\mathrm{n}=1,112)$ of quarters were excluded from analysis because of contaminated milk samples. Consequently, 10,448 quarters from 2,889 cows from 78 herds were available for the final analysis.

\section{Intramammary Infection}

The quarter-level prevalence of ALL-IMI was 21.05\% $(2,199 / 10,448$; Table 1); $50.4 \%$ of cows had at least one quarter with an IMI. The quarter-level prevalence of IMI caused by pathogen groups were NAS (11.4\%), Staphylococcus aureus (0.4\%), SSLO (5.6\%), other gram-positive bacteria (3.9\%), gram-negative bacteria $(0.8 \%)$, and other pathogens $(0.2 \%)$. Note that these prevalences do not sum to the overall prevalence of IMI $(21.05 \%)$ because some quarters were infected with 2 pathogens $(\mathrm{n}=147)$. The most common bacterial species was Staphylococcus chromogenes, which infected $6.9 \%$ of quarters. Other common causes of IMI included Aerococcus spp. (2.0\%), Bacillus spp. (1.9\%), Lactococcus spp. (1.8\%), and Corynebacterium spp. (1.2\%). Staphylococcus aureus (0.4\%), Streptococcus dysga- lactiae (0.3\%), Streptococcus uberis (0.3\%), coliforms $(0.1 \%)$, and Prototheca spp. $(<0.1 \%)$ were uncommon causes of IMI. Intramammary infection prevalence at the herd level was similar to that observed overall. The average proportion of infected quarters per herd was $21.5 \%(\mathrm{SD}=9.5 \%)$ for all IMI, $11.3 \%(\mathrm{SD}=6.7 \%)$ for NAS, $4.8 \%(\mathrm{SD}=4.8 \%)$ for $\mathrm{SSLO}$, and $0.1 \%(\mathrm{SD}=$ $0.4 \%$ ) for coliforms (Table 2). The average proportion of cows with at least one infected quarter per herd was $50.5 \%(\mathrm{SD}=13.8 \%)$ for all IMI, $29.5 \%(\mathrm{SD}=13.7 \%)$ for NAS, $16.8 \%(\mathrm{SD}=11.7 \%)$ for SSLO, and $0.5 \%$ $(\mathrm{SD}=1.3 \%)$ for coliforms. The interclass correlation coefficients (a statistic used to describe clustering of hierarchical data) for herd and cow were 0.06 and 0.18 , respectively, when fitting a random effects model for ALL-IMI.

\section{Bedding Bacteria Count}

One hundred forty-eight unused and 150 used bedding samples from eligible herds were included in analysis. Median bacteria counts $\left(\log _{10} \mathrm{cfu} / \mathrm{mL}\right)$ for each pathogen group for RMS, NSA, ON, and RSA are shown in Table 3 and in Figures 2 and 3. All methods for reporting BBC $\left(\log _{10}\right.$ cfu per $\mathrm{mL}, \log _{10}$ cfu per $\mathrm{g}$ of wet, and $\log _{10}$ cfu per $g$ of DM) were highly correlated with each other (Kendall's tau >0.87). Consequently, only the results using $\log _{10}$ cfu per $\mathrm{mL}$ are reported. The median (interquartile range; IQR) total bacteria count in unused bedding was RMS (6.28; 5.34-6.80), NSA $(4.31 ; 4.04-4.83)$, ON $(3.17 ; 1.88-4.88)$, and RSA (5.90; 5.22-6.39). For used bedding, the median (IQR) total bacteria count was RMS $(6.95 ; 6.88-7.12)$, NSA (6.91; 6.85-7.11), ON (6.66; 6.04-6.90), and RSA (6.85; 6.80-6.94). The proportion of unused bedding samples with no bacterial colonies isolated (reported as $1.1 \log _{10}$ $\mathrm{cfu} / \mathrm{mL}$ in Table 1) was RMS $(0 \%)$, NSA $(0 \%)$, ON (12.5\%), and RSA (0\%). Bacterial colonies were isolated from all used bedding samples. The proportion of unused bedding samples with no Staphylococcus spp. colonies was RMS (55.0\%), NSA (56.8\%), ON (53.1\%), and RSA (59.0\%). The proportion of used bedding samples with no Staphylococcus spp. colonies was RMS (26.2\%), NSA (73.0\%), ON (15.6\%), and RSA (43.6\%). The proportion of unused bedding samples with no SSLO colonies was RMS (47.5\%), NSA (51.4\%), ON (65.6\%), and RSA (33.3\%). The proportion of used bedding samples with no SSLO colonies was RMS (14.3\%), NSA (13.5\%), ON (9.4\%), and RSA $(7.7 \%)$. No Prototheca spp. were isolated in any bedding samples. The proportion of used bedding samples with counts of SSLO at the upper detection limit $\left(6.80 \log _{10} \mathrm{cfu} / \mathrm{mL}\right)$ was RMS (28.6\%), NSA (29.7\%), ON (18.8\%), and RSA (7.7\%). 
Table 1. Quarter-level prevalence of IMI from 2,889 late gestation cows, stratified by bedding material exposure

\begin{tabular}{|c|c|c|c|c|c|c|c|c|c|c|}
\hline \multirow[b]{2}{*}{ Item } & \multicolumn{2}{|c|}{$\begin{array}{l}\text { Manure } \\
\text { solids }\end{array}$} & \multicolumn{2}{|c|}{$\begin{array}{l}\text { New } \\
\text { sand }\end{array}$} & \multicolumn{2}{|c|}{$\begin{array}{l}\text { Organic } \\
\text { nonmanure }\end{array}$} & \multicolumn{2}{|c|}{$\begin{array}{l}\text { Recycled } \\
\text { sand }\end{array}$} & \multicolumn{2}{|c|}{ All } \\
\hline & No. & $\%$ & No. & $\%$ & No. & $\%$ & No. & $\%$ & No. & $\%$ \\
\hline Total quarters sampled & 3,286 & & 2,842 & & 2,450 & & 2,982 & & 11,560 & \\
\hline Contaminated & 221 & 6.73 & 288 & 10.13 & 252 & 10.29 & 351 & 11.75 & 1,112 & 9.62 \\
\hline $\begin{array}{l}\text { Total quarters at risk } \\
\text { (excluding contaminated) }\end{array}$ & 3,065 & 100.00 & 2,554 & 100.00 & 2,198 & 100.00 & 2,631 & 100.00 & 10,448 & 100.00 \\
\hline No growth & 2,475 & 80.75 & 1,943 & 76.08 & 1,699 & 77.30 & 2,132 & 81.03 & 8,249 & 78.95 \\
\hline Infected quarters & 590 & 19.25 & 611 & 23.92 & 499 & 22.70 & 499 & 18.97 & 2,199 & 21.05 \\
\hline Single pathogen & 564 & 18.40 & 570 & 22.32 & 455 & 20.70 & 463 & 17.60 & 2,052 & 19.64 \\
\hline Mixed infection & 26 & 0.85 & 41 & 1.61 & 44 & 2.00 & 36 & 1.37 & 147 & 1.41 \\
\hline Gram positive $^{1}$ & 585 & 19.09 & 583 & 22.83 & 463 & 21.06 & 479 & 18.21 & 2,110 & 20.20 \\
\hline Staphylococcus aureus & 17 & 0.55 & 10 & 0.39 & 9 & 0.41 & 8 & 0.30 & 44 & 0.42 \\
\hline NAS & 388 & 12.66 & 320 & 12.53 & 238 & 10.83 & 241 & 9.16 & 1,187 & 11.36 \\
\hline Staphylococcus chromogenes & 297 & 9.69 & 186 & 7.28 & 109 & 4.96 & 133 & 5.06 & 725 & 6.94 \\
\hline Staphylococcus epidermidis & 4 & 0.13 & 13 & 0.51 & 24 & 1.09 & 7 & 0.27 & 48 & 0.46 \\
\hline Staphylococcus haemolyticus & 9 & 0.29 & 16 & 0.63 & 12 & 0.55 & 9 & 0.34 & 46 & 0.44 \\
\hline Staphylococcus hominis & 0 & 0.00 & 0 & 0.00 & 1 & 0.05 & 4 & 0.15 & 5 & 0.05 \\
\hline Staphylococcus sciuri & 20 & 0.65 & 12 & 0.47 & 5 & 0.23 & 2 & 0.08 & 39 & 0.37 \\
\hline Staphylococcus simulans & 8 & 0.26 & 19 & 0.74 & 3 & 0.14 & 33 & 1.25 & 63 & 0.60 \\
\hline Staphylococcus sp. & 48 & 1.57 & 45 & 1.76 & 74 & 3.37 & 56 & 2.13 & 223 & 2.13 \\
\hline Staphylococcus xylosus/saprophyticus & 9 & 0.29 & 32 & 1.25 & 15 & 0.68 & 1 & 0.04 & 57 & 0.55 \\
\hline $\begin{array}{l}\text { Streptococcus spp. and Streptococcus- } \\
\text { like organisms }\end{array}$ & 61 & 1.99 & 181 & 7.09 & 147 & 6.69 & 191 & 7.26 & 580 & 5.55 \\
\hline Aerococcus sp. & 3 & 0.10 & 13 & 0.51 & 5 & 0.23 & 13 & 0.49 & 34 & 0.33 \\
\hline Aerococcus viridans & 11 & 0.36 & 46 & 1.80 & 75 & 3.41 & 45 & 1.71 & 177 & 1.69 \\
\hline Enterococcus faecalis & 0 & 0.00 & 2 & 0.08 & 0 & 0.00 & 0 & 0.00 & 2 & 0.02 \\
\hline Enterococcus hirae & 2 & 0.07 & 0 & 0.00 & 0 & 0.00 & 4 & 0.15 & 6 & 0.06 \\
\hline Enterococcus saccarolyticus & 4 & 0.13 & 2 & 0.08 & 6 & 0.27 & 10 & 0.38 & 22 & 0.21 \\
\hline Enterococcus sp. & 5 & 0.16 & 8 & 0.31 & 22 & 1.00 & 7 & 0.27 & 42 & 0.40 \\
\hline Lactococcus garvieae & 2 & 0.07 & 53 & 2.08 & 2 & 0.09 & 70 & 2.66 & 127 & 1.22 \\
\hline Lactococcus lactis & 5 & 0.16 & 24 & 0.94 & 5 & 0.23 & 13 & 0.49 & 47 & 0.45 \\
\hline Lactococcus sp. & 0 & 0.00 & 7 & 0.27 & 0 & 0.00 & 6 & 0.23 & 13 & 0.12 \\
\hline Streptococcus dysgalactiae & 8 & 0.26 & 3 & 0.12 & 18 & 0.82 & 4 & 0.15 & 33 & 0.32 \\
\hline Streptococcus sp. & 6 & 0.20 & 19 & 0.74 & 13 & 0.59 & 14 & 0.53 & 52 & 0.50 \\
\hline Streptococcus uberis & 17 & 0.55 & 5 & 0.20 & 5 & 0.23 & 5 & 0.19 & 32 & 0.31 \\
\hline Other gram-positive bacteria & 134 & 4.37 & 106 & 4.36 & 96 & 4.37 & 66 & 2.51 & 402 & 3.85 \\
\hline Arthrobacter gandavensis & 0 & 0.00 & 1 & 0.04 & 0 & 0.00 & 0 & 0.00 & 1 & 0.01 \\
\hline Arthrobacter sp. & 0 & 0.00 & 2 & 0.08 & 0 & 0.00 & 0 & 0.00 & 2 & 0.02 \\
\hline Bacillus sp. & 79 & 2.58 & 46 & 1.80 & 44 & 2.00 & 28 & 1.06 & 197 & 1.89 \\
\hline Corynebacterium sp. & 22 & 0.72 & 41 & 1.61 & 37 & 1.68 & 21 & 0.80 & 121 & 1.16 \\
\hline Listeria monocytogenes & 1 & 0.03 & 0 & 0.00 & 0 & 0.00 & 0 & 0.00 & 1 & 0.01 \\
\hline Micrococcus sp. & 5 & 0.16 & 2 & 0.08 & 0 & 0.00 & 1 & 0.04 & 8 & 0.08 \\
\hline Trueperella pyogenes & 2 & 0.07 & 0 & 0.00 & 1 & 0.05 & 1 & 0.04 & 4 & 0.04 \\
\hline Gram-positive cocci & 21 & 0.69 & 6 & 0.23 & 8 & 0.36 & 7 & 0.27 & 42 & 0.40 \\
\hline Gram-positive rod & 5 & 0.16 & 8 & 0.31 & 6 & 0.27 & 8 & 0.30 & 27 & 0.26 \\
\hline Gram-negative bacteria & 5 & 0.16 & 29 & 1.14 & 33 & 1.50 & 21 & 0.80 & 88 & 0.84 \\
\hline Coliforms & 1 & 0.03 & 7 & 0.27 & 3 & 0.14 & 4 & 0.15 & 15 & 0.14 \\
\hline Citrobacter sp. & 1 & 0.03 & 1 & 0.04 & 0 & 0.00 & 1 & 0.04 & 3 & 0.03 \\
\hline Escherichia coli & 0 & 0.00 & 1 & 0.04 & 2 & 0.09 & 0 & 0.00 & 3 & 0.03 \\
\hline Escherichia sp. & 0 & 0.00 & 1 & 0.04 & 0 & 0.00 & 0 & 0.00 & 1 & 0.01 \\
\hline Klebsiella pneumoniae & 0 & 0.00 & 1 & 0.04 & 0 & 0.00 & 0 & 0.00 & 1 & 0.01 \\
\hline Serratia marcescens & 0 & 0.00 & 1 & 0.04 & 1 & 0.05 & 0 & 0.00 & 2 & 0.02 \\
\hline Serratia sp. & 0 & 0.00 & 2 & 0.08 & 0 & 0.00 & 3 & 0.11 & 5 & 0.05 \\
\hline Other gram-negative bacteria & 4 & 0.13 & 22 & 0.86 & 30 & 1.36 & 17 & 0.65 & 73 & 0.70 \\
\hline Gram-negative organism & 3 & 0.10 & 8 & 0.86 & 21 & 0.96 & 10 & 0.38 & 42 & 0.40 \\
\hline Pantoea sp. & 0 & 0.00 & 3 & 0.12 & 1 & 0.05 & 2 & 0.08 & 6 & 0.06 \\
\hline Pseudomonas aeruginosa & 0 & 0.00 & 0 & 0.00 & 0 & 0.00 & 1 & 0.04 & 1 & 0.01 \\
\hline Pseudomonas sp. & 0 & 0.00 & 11 & 0.43 & 7 & 0.32 & 4 & 0.15 & 22 & 0.21 \\
\hline Raoultella $\mathrm{sp}$ & 0 & 0.00 & 0 & 0.00 & 1 & 0.05 & 0 & 0.00 & 1 & 0.01 \\
\hline Stenotrophomonas maltophilia & 1 & 0.03 & 0 & 0.00 & 0 & 0.00 & 0 & 0.00 & 1 & 0.01 \\
\hline Other organisms & 1 & 0.03 & 2 & 0.08 & 11 & 0.50 & 4 & 0.15 & 18 & 0.17 \\
\hline Yeast & 1 & 0.03 & 2 & 0.08 & 11 & 0.50 & 3 & 0.11 & 17 & 0.16 \\
\hline Prototheca sp. & 0 & 0.00 & 0 & 0.00 & 0 & 0.00 & 1 & 0.04 & 1 & 0.01 \\
\hline
\end{tabular}

${ }^{1}$ Reported frequencies of bacteria groups (e.g., gram positive) are the not the same as the sum of bacteria species within the group due to mixed infections in 147 quarters. 
Table 2. Herd-level prevalence of IMI in 78 dairy herds in the United States ${ }^{1}$

\begin{tabular}{|c|c|c|c|c|c|c|c|c|}
\hline \multirow[b]{2}{*}{ IMI measure } & \multicolumn{4}{|c|}{$\begin{array}{l}\text { Infected quarters per herd } \\
\quad(\% ; \mathrm{n}=78 \text { herds })\end{array}$} & \multicolumn{4}{|c|}{$\begin{array}{l}\text { Infected cows }{ }^{2} \text { per herd } \\
\quad(\% ; \mathrm{n}=78 \text { herds })\end{array}$} \\
\hline & Mean & $\mathrm{SD}$ & Minimum & Maximum & Mean & $\mathrm{SD}$ & Minimum & Maximum \\
\hline NAS & 11.3 & 6.7 & 0.0 & 37.0 & 29.5 & 13.7 & 0.0 & 67.6 \\
\hline Streptococcus spp. and Streptococcus-like organisms & 4.8 & 4.8 & 0.0 & 26.4 & 16.8 & 11.5 & 0.0 & 44.4 \\
\hline Coliforms & 0.1 & 0.4 & 0.0 & 1.8 & 0.5 & 1.3 & 0.0 & 5.4 \\
\hline
\end{tabular}

${ }^{1}$ Note that 40 cows (160 quarters) were sampled from each herd, irrespective of herd size. Therefore, herd-level inference may be limited by this sampling strategy.

${ }^{2}$ Cows with at least one infected quarter.

\section{Association Between Bedding Bacteria Counts and Intramammary Infection}

Odds ratio estimates of the associations between counts of all bacteria, Staphylococcus spp., and SSLO in bedding and odds of ALL-IMI, NAS-IMI, and SSLOIMI, respectively, are shown in Figures 4, 5, and 6. Similar associations were identified when using alternative $\mathrm{BBC}$ units (cfu/g of wet or $\mathrm{cfu} / \mathrm{g}$ of DM) or when categorical $\mathrm{BBC}$ variables were used. Consequently, only estimates from models using $\mathrm{BBC}$ as a continuous predictor, measured on the $\log _{10}$ cfu per $\mathrm{mL}$ scale, are reported.

Unused Bedding. In unused bedding, total bacteria count was associated with odds of ALL-IMI (OR = 1.08; 95\% CI: 1.00-1.17, Figure 3), as was SSLO count and SSLO-IMI $(\mathrm{OR}=1.09 ; 95 \%$ CI: $1.00-1.19$, Figure 5), but not Staphylococcus spp. count and NAS-IMI $(\mathrm{OR}=0.98 ; 95 \%$ CI: 0.91-1.05, Figure 4). No statistical evidence was observed of effect modification by bedding type in unused bedding (Wald test for BBC $\times$ bedding type interaction term was $P>0.05$ in models for ALL-IMI, NAS-IMI, and SSLO-IMI). Nevertheless, stratified models were created. Odds ratio estimates were generally consistent across the 4 common bedding types for the association between total bacteria count and ALL-IMI and Staphylococcus spp. count and odds of NAS-IMI. The associations between SSLO count and SSLO-IMI were more variable between bedding types, with positive $\mathrm{OR}$ estimates in RMS (OR $=1.06 ; 95 \%$ CI: $0.78-1.45), \mathrm{ON}(\mathrm{OR}=1.55 ; 95 \%$ CI: $1.18-2.03)$, and RSA $(\mathrm{OR}=1.13 ; 95 \%$ CI: $1.02-1.25)$ and a negative association for NSA (OR $=0.82 ; 95 \%$ CI: 0.68-0.99).

Used Bedding. The association between $\mathrm{BBC}$ in used bedding and odds of IMI varied considerably by bedding type (Wald test for interaction terms for BBC $\times$ bedding type was $P<0.05$ in models for ALL-IMI, NAS-IMI, and SSLO-IMI). Main effects models (i.e., models omitting the interaction with bedding type) indicated an overall positive association between total bacteria count and ALL-IMI (OR $=1.41 ; 95 \%$ CI: 1.11-1.81, Figure 3), and possibly between Staphylococ-

Table 3. Median (interquartile range) bacteria counts (log cfu/mL) for unused ( $\mathrm{n}=148)$ and used $(\mathrm{n}=150)$ bedding samples taken from 78 $\operatorname{herds}^{1}$

\begin{tabular}{|c|c|c|c|c|c|c|c|c|}
\hline \multirow{2}{*}{$\begin{array}{l}\text { Item } \\
\text { Unused bedding }\end{array}$} & \multicolumn{2}{|c|}{ Manure solids } & \multicolumn{2}{|c|}{ New sand } & \multicolumn{2}{|c|}{ Organic non-manure } & \multicolumn{2}{|c|}{ Recycled sand } \\
\hline & & & & & & & & \\
\hline Total bacteria count & 6.28 & $(5.34-6.80)$ & 4.31 & $(4.04-4.83)$ & 3.17 & $(1.88-4.88)$ & 5.90 & $(5.22-6.39)$ \\
\hline Staphylococcus spp. & 1.10 & $(1.10-4.28)$ & 1.10 & $(1.10-2.35)$ & 1.10 & $(1.10-2.10)$ & 1.10 & $(1.10-3.49)$ \\
\hline $\mathrm{SSLO}^{2}$ & 3.33 & $(1.10-4.91)$ & 1.10 & $(1.10-2.40)$ & 1.10 & $(1.10-2.21)$ & 3.40 & $(1.10-4.88)$ \\
\hline Coliform & 1.25 & $(1.10-3.40)$ & 1.10 & $(1.10-1.10)$ & 1.10 & $(1.10-2.92)$ & 1.10 & $(1.10-1.94)$ \\
\hline Klebsiella spp. & 1.10 & $(1.10-1.10)$ & 1.10 & $(1.10-1.10)$ & 1.10 & $(1.10-1.10)$ & 1.10 & $(1.10-1.10)$ \\
\hline Noncoliform gram negative & 4.87 & $(3.38-5.77)$ & 2.00 & $(1.40-2.93)$ & 1.90 & $(1.10-3.82)$ & 4.40 & $(3.35-4.66)$ \\
\hline Bacillus spp. & 6.11 & $(5.33-6.80)$ & 4.30 & $(3.83-4.81)$ & 2.80 & $(1.32-4.65)$ & 5.81 & $(5.19-6.24)$ \\
\hline \multicolumn{9}{|l|}{ Used bedding } \\
\hline Total bacteria count & 6.95 & $(6.88-7.12)$ & 6.91 & $(6.85-7.11)$ & 6.66 & $(6.04-6.90)$ & 6.85 & $(6.80-6.94)$ \\
\hline Staphylococcus spp. & 4.49 & $(1.17-5.47)$ & 1.10 & $(1.10-2.54)$ & 5.01 & $(2.86-5.61)$ & 3.40 & $(1.10-4.88)$ \\
\hline SSLO & 6.01 & $(5.38-6.80)$ & 5.85 & $(5.40-6.80)$ & 5.83 & $(5.40-6.30)$ & 5.63 & $(5.18-6.01)$ \\
\hline Coliform & 4.79 & $(3.64-5.35)$ & 3.65 & $(3.32-4.35)$ & 3.47 & $(2.07-4.89)$ & 3.18 & $(2.58-3.57)$ \\
\hline Klebsiella spp. & 1.10 & $(1.10-1.10)$ & 1.10 & $(1.10-1.10)$ & 1.10 & $(1.10-1.10)$ & 1.10 & $(1.10-1.10)$ \\
\hline Noncoliform gram negative & 5.77 & $(5.31-6.31)$ & 5.68 & $(5.17-6.04)$ & 4.83 & $(4.06-5.55)$ & 5.27 & $(4.98-5.70)$ \\
\hline Bacillus spp. & 6.80 & $(6.80-6.80)$ & 6.80 & $(6.80-6.80)$ & 5.68 & $(4.86-6.49)$ & 6.80 & $(6.78-6.80)$ \\
\hline
\end{tabular}

${ }^{1}$ No Prototheca spp. colonies were identified in any bedding samples.

${ }^{2} \mathrm{SSLO}=$ Streptococcus spp. and Streptococcus-like organisms. 

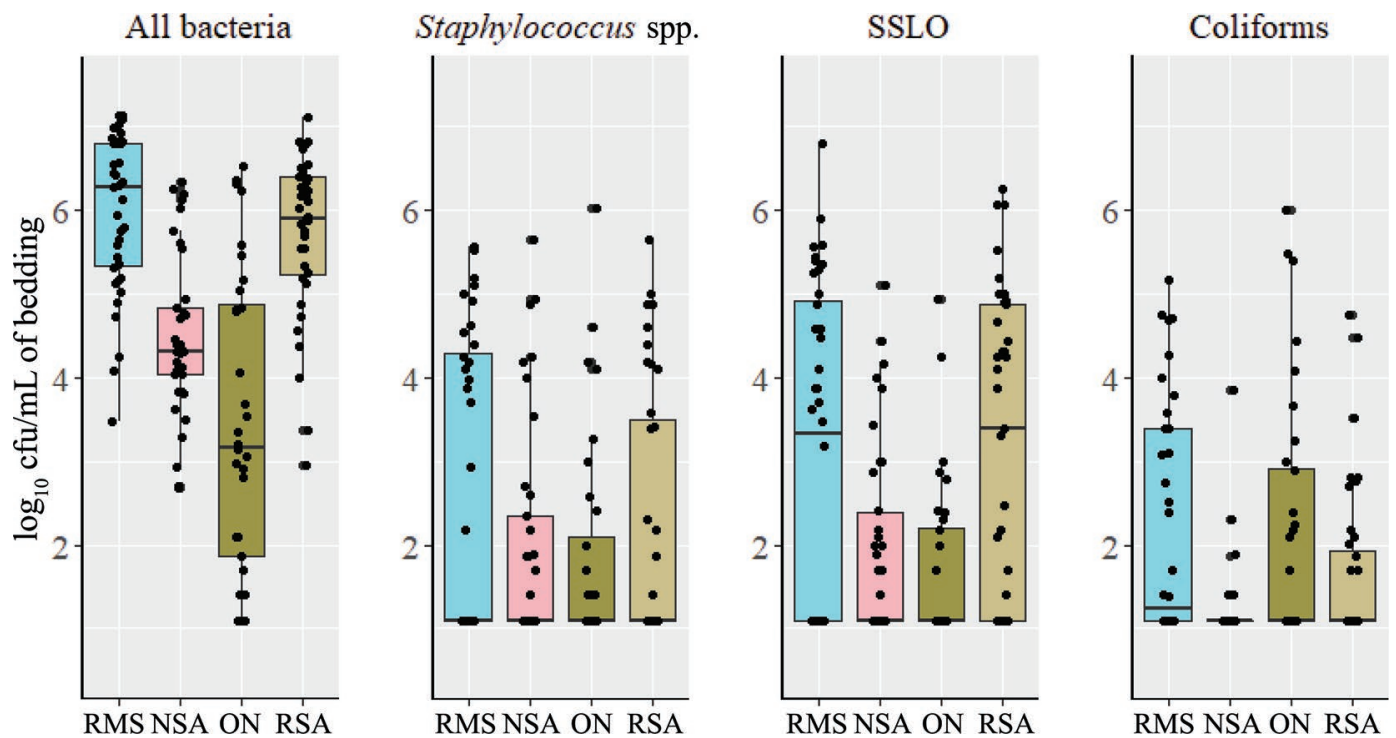

Figure 2. Unused bedding. Boxplots showing 25th, 50th (median), and 75th percentiles of bacteria counts in 148 unused bedding samples collected from 76 herds. Lower and upper whiskers extend from the 25 th and 75 th percentiles to the furthest data point that is within $1.5 \times$ the interquartile range distance from the 25 th and 75 th percentiles, respectively. Black dots indicate data points, which can be seen as clusters at $1 / 2$ $\times$ lower detection limit $(1.1 \log \mathrm{cfu} / \mathrm{mL})$. The upper detection limit for all counts except "All bacteria" is $6.8 \mathrm{log}$ cfu/mL. SSLO = Streptococcus and Streptococcus-like organisms; RMS = manure solids $(\mathrm{n}=21$ herds, 40 samples); NSA = new sand $(\mathrm{n}=20$ herds, 37 samples); ON = organic non-manure ( $\mathrm{n}=16$ herds, 32 samples); RSA = recycled sand $(\mathrm{n}=21$ herds, 39 samples). Note that the number of herds does not sum to 76 because some herds switched bedding material type between sampling periods.

cus spp. and NAS-IMI (OR = 1.05; 95\% CI: 0.99-1.10, Figure 4) and between SSLO and SSLO-IMI (OR = 1.07; 95\% CI: 0.99-1.16, Figure 5). However, OR estimates for the association between total bacteria counts in used bedding and odds of ALL-IMI, after stratifying by bedding type, indicated a positive association in quarters exposed to RMS (OR $=2.29 ; 95 \%$ CI: 1.15 $4.54)$ and $\mathrm{ON}(\mathrm{OR}=1.51 ; 95 \% \mathrm{CI}: 1.09-2.09)$, and a negative association in quarters exposed to NSA (OR = $0.47 ; 95 \%$ CI: $0.26-0.87)$. In quarters exposed to RSA, total bacteria count in used bedding and odds of ALLIMI showed little evidence of association $(\mathrm{OR}=0.83$, 95\% CI: 0.54-1.27). A similar pattern of effect modification was evident for the association with Staphylococcus spp. count in used bedding and odds of NAS-IMI, with positive associations in quarters exposed to RMS $(\mathrm{OR}=1.10 ; 95 \% \mathrm{CI}: 1.02-1.19)$ and $\mathrm{ON}(\mathrm{OR}=1.18$; 95\% CI: $1.05-1.32$ ), and negative association in quarters exposed to NSA $(\mathrm{OR}=0.83 ; 95 \% \mathrm{CI}: 0.72-0.95)$. Little evidence was observed of an association between Staphylococcus spp. count in used bedding and odds of NAS-IMI in quarters exposed to RSA (OR $=0.98 ; 95 \%$ CI: 0.88-1.09). Estimates for the association between SSLO count in used bedding and odds of SSLO-IMI were less precise than other models, with little evidence for associations among quarters exposed to RMS (OR $=0.95 ; 95 \%$ CI: $0.69-1.30), \mathrm{NSA}(\mathrm{OR}=0.95 ; 95 \%$ CI:
0.85-1.07), and RSA (OR $=1.10 ; 95 \%$ CI: 0.95-1.26). The association between SSLO count in used bedding and odds of SSLO-IMI in quarters exposed to ON bedding was positive (OR $=1.61,95 \%$ CI: $1.20-2.16)$.

\section{Associations Among Bedding Type, Season of Sampling, and Intramammary Infection}

Only modest differences in IMI prevalence were found when comparing quarters exposed to RMS (19.3\%), NSA (23.9\%), ON (22.7\%), and RSA bedding (19.0\%; Table 1). Odds of SSLO-IMI was lower in RMS-exposed quarters (2.0\%) when compared with quarters exposed to other bedding material types: RSA $(7.3 \%, \mathrm{OR}=3.53,95 \%$ CI: $2.23-5.58), \mathrm{NSA}(7.1 \%$; $\mathrm{OR}=3.53,95 \%$ CI: $2.28-5.47)$, and $\mathrm{ON}(6.7 \%$; OR = 3.29, 95\% CI: 2.10-5.16; Supplemental Table S1, https: //doi.org/10.3168/jds.2019-17074). Lactococcus spp. IMI were higher in quarters exposed to NSA (3.3\%) and RSA $(3.4 \%)$ than those exposed to RMS $(0.2 \%)$ and $\mathrm{ON}(0.3 \%)$. Exploratory analysis with multivariable logistic regression with mixed effects found that quarters exposed to inorganic bedding (NSA or RSA) had much higher odds of Lactococcus spp. IMI than quarters exposed to organic (RMS or ON) bedding (OR $=11.02 ; 95 \%$ CI: $2.70-30.42)$. Prevalence of NAS-IMI was somewhat similar between bedding types except 
for a lower prevalence in quarters exposed to RSA than RMS (9.2 vs. $12.7 \%$; OR $=0.56,95 \%$ CI: $0.36-0.87$ ). Quarters sampled during winter 2017-2018 had a lower prevalence of IMI $(18.9 \%, \mathrm{OR}=0.75 ; 95 \% \mathrm{CI}$ : 0.66-0.84) than quarters sampled during summer 2017 (23.1\%). This was due to a lower prevalence of NASIMI in the winter period (9.6 vs. $13.10 \%, \mathrm{OR}=0.64$; 95\% CI: $0.54-0.76)$.

\section{DISCUSSION}

\section{Prevalence of Intramammary Infection in Late-Lactation Cows}

To our knowledge, this is the largest survey of IMI in cows approaching dry-off in the United States. The quarter-level prevalence of ALL-IMI was 21.1\%. In other recent surveys of cows at dry-off in US herds, the prevalence of IMI was 12.8\% (Pantoja et al., 2009), $19.2 \%$ (Arruda et al., 2013), and $34.7 \%$ (Johnson et al., 2016). The prevalence found in our study is likely to be a more accurate prevalence estimate than the aforementioned studies, which only enrolled 11 herds between them. The low prevalence found in this study indicates that antibiotic use at dry-off could be reduced in North American dairy herds by implementing selective DCT (Cameron et al., 2014; Vasquez et al., 2018). The finding that $50.5 \%$ of cows in our study had at least one infected quarter (compared with the 21.1\% quarter-level prevalence) indicates that implementing selective DCT at the quarter level (Patel et al., 2017) could reduce antibiotic treatments more than programs implemented at the cow level (Vasquez et al., 2018). To our knowledge, antibiotic reductions from quarter and cow-level selective DCT approaches have not been compared within a single study. More than half of ALLIMI were caused by NAS (11.4\%), which are likely to have a high spontaneous dry period cure risk (Vasquez et al., 2018) and often have minimal effects on clinical mastitis risk (Green et al., 2002) or milk production in the subsequent lactation (Vanderhaeghen et al., 2014). More research is needed to understand the effect of NAS-IMI at dry-off on udder health in the subsequent lactation, so that selective DCT programs can be optimized to either treat or withhold treatment from NAS infected quarters.

The prevalence of SSLO in this study was 5.6\%, which consisted of Aerococcus spp. (2.0\%), Lactococcus spp. (1.8\%), Streptococcus spp. (1.1\%), and Enterococcus spp. (0.7\%). Distinguishing between genera and species within the SSLO category has recently improved with the inclusion of MALDI-TOF in diagnostic laboratories. Research is needed to describe the contrasting epidemiologic characteristics of these pathogens because most epidemiologic studies of SSLO IMI were conducted using traditional laboratory methods.
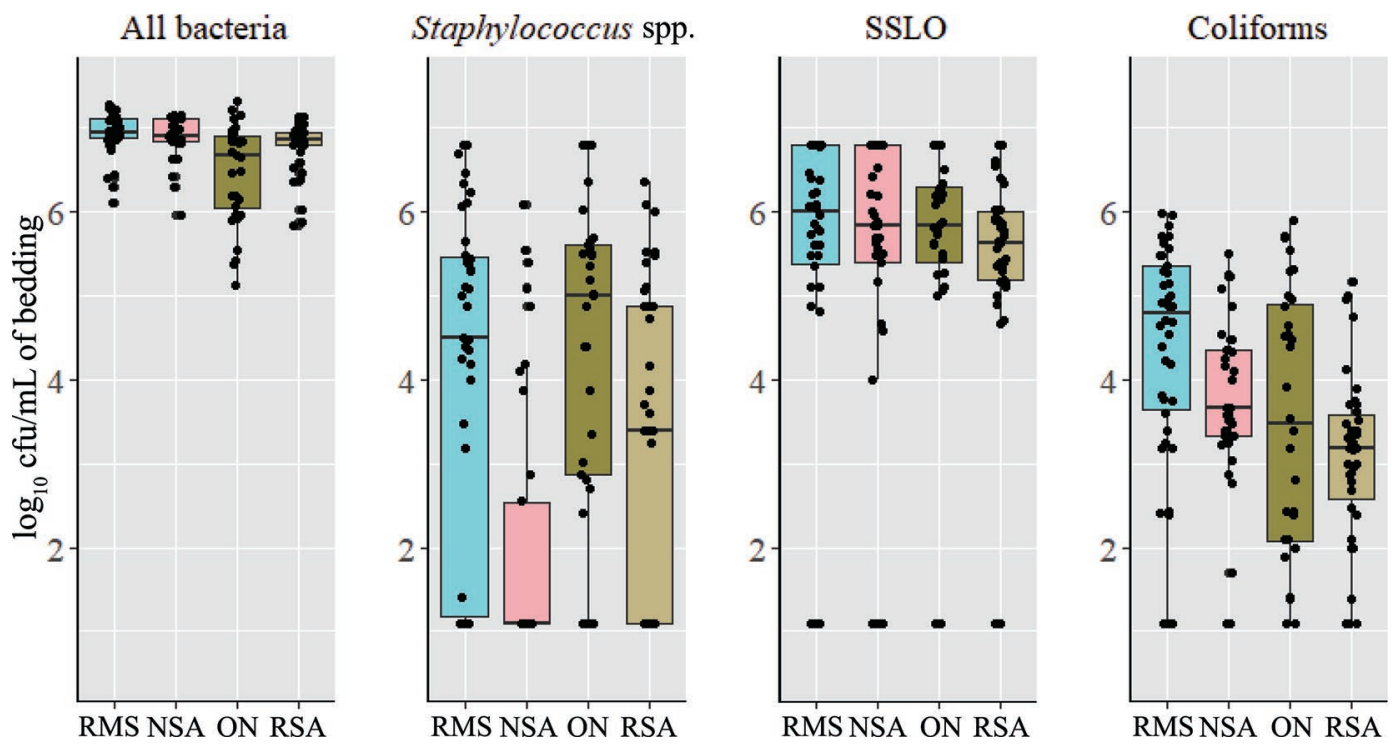

Figure 3. Used bedding. Boxplots showing 25th, 50th (median), and 75th percentiles of bacteria counts in 148 used bedding samples collected from 78 herds. Black dots indicate data points, which can be seen as clusters at $1 / 2 \times$ lower detection limit $(1.1 \mathrm{log}$ cfu/mL). The upper detection limit for all counts except "All bacteria" is $6.8 \mathrm{log} \mathrm{cfu} / \mathrm{mL}$. SSLO = Streptococcus and Streptococcus-like organisms; RMS $=$ manure solids ( $\mathrm{n}=23$ herds, 42 samples); NSA = new sand $(\mathrm{n}=20$ herds, 37 samples); ON = organic non-manure ( $\mathrm{n}=16$ herds, 32 samples); and $\mathrm{RSA}=$ recycled sand $(\mathrm{n}=21$ herds, 39 samples $)$. Note that the number of herds does not sum to 78 because some herds switched bedding material type between sampling periods. 


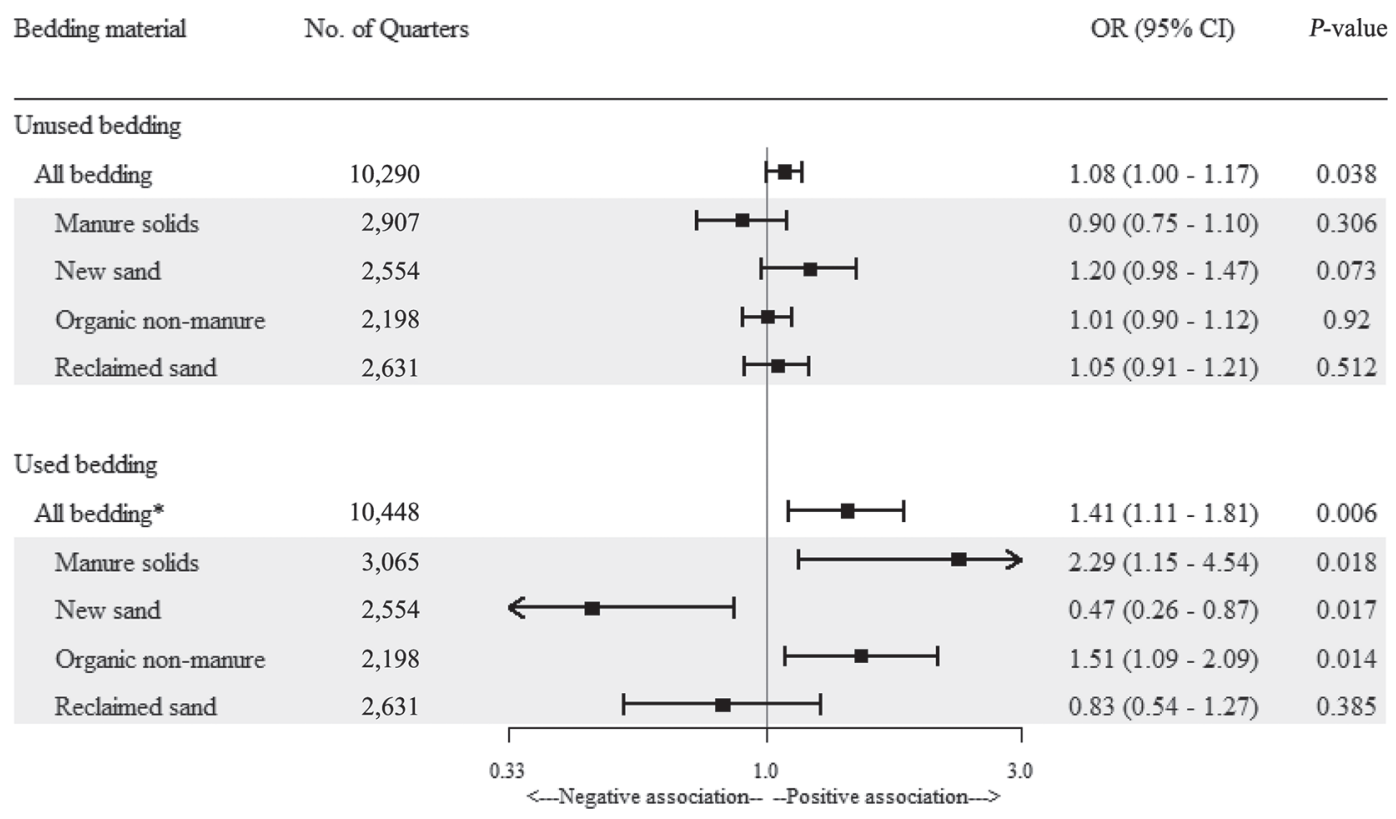

Figure 4. Models for quarters infected with at least one pathogen. Odds ratio (OR) estimates and $95 \%$ CI from 10 multivariable logistic regression with mixed effects models investigating the association between bacteria levels in bedding and IMI (all pathogens). Beta coefficients for covariates are not reported for clarity. *Interaction between bedding bacteria count and bedding type: main effects model reported.

Recent research suggests that they are not a homogeneous group. For example, reports have suggested that Aerococcus spp. is a teat apex commensal (Braem et al., 2012) and that IMI caused by this pathogen do not have an effect on udder health (Wyder et al., 2011). In contrast, case reports have documented herd outbreaks of clinical mastitis caused by Lactococcus spp. (Werner et al., 2014; Rodrigues et al., 2016).

In our study, IMI in late-lactation cows were mostly caused by gram-positive bacteria, which accounted for $96.0 \%$ of infected quarters. Interestingly, only one quarter was infected with Prototheca spp. and no colonies were isolated from bedding, indicating that the herdlevel prevalence of Prototheca spp. may be low in latelactation cows in US dairy herds. However, specialized media were not used in the culture of milk or bedding, which may have reduced detection sensitivity. In our study, all cultures were performed by an experienced microbiologist using media that can successfully isolate Prototheca spp. (Lass-Flörl and Mayr, 2007). Previous studies have isolated Prototheca spp. from bedding material, but the importance of bedding material in the pathogenesis of Prototheca mastitis is still unclear (Ricchi et al., 2010).

Less than $1 \%$ of quarters were infected with gramnegative bacteria, which accounted for only $3.3 \%$ of infected quarters (Table 1). Furthermore, only $0.14 \%$ quarters were infected with coliform bacteria overall, and the average herd prevalence of coliform infected quarters and cows was also very low, which was consistent across all herds in this study (Table 2). Longitudinal studies of IMI in dairy cattle have shown that the prevalence of IMI caused by coliforms decreases as cows approach dry-off (Smith et al., 1985; Bradley et al., 2015). Other surveys of IMI at dry-off have also reported a very low prevalence of coliform infections, including 0.9 (Hogan et al., 1989), 1.27 (Bradley et al., 2015), 2.2 (Arruda et al., 2013), and 2.7\% (Johnson et al., 2016).

The low prevalence of coliform IMI in our study, and others, suggests that DCT in US dairy herds should primarily target gram-positive bacteria, and may explain why IMI cure risk during the dry period appears to be similar when using narrow- or broad-spectrum antimicrobials (Arruda et al., 2013; Johnson et al., 2016). However, some herds may benefit from the use of broad-spectrum antimicrobials at dry-off. One small trial conducted by Pinedo et al. (2012) in 2 Florida herds found that treatment with a narrow-spectrum antibiotic $(1,000,000$ IU of procaine penicillin $\mathrm{G}$ and 1 $\mathrm{g}$ of dihydrostreptomycin) resulted in higher incidences of clinical and subclinical mastitis in the first $60 \mathrm{~d}$ after calving, as compared with treatment with a broadspectrum product (500 $\mathrm{mg}$ of ceftiofur hydrochloride). However, those results differ from a larger randomized trial conducted in 6 herds in 4 states, which showed no 


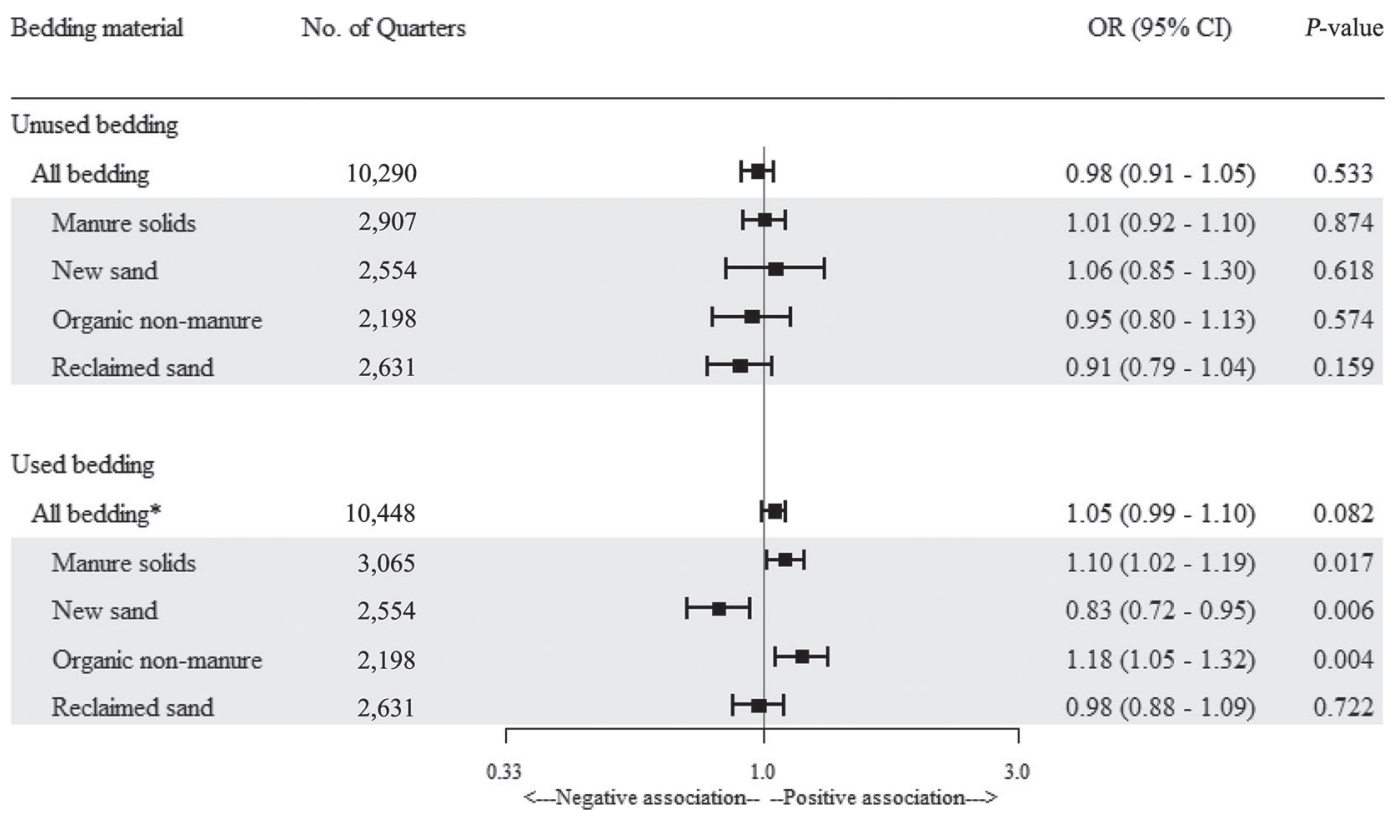

Figure 5. Non-aureus Staphylococcus spp.-IMI models. Odds ratio (OR) estimates and 95\% CI from 10 multivariable logistic regression with mixed effects models investigating the association between bacteria levels in bedding and IMI caused by non-aureus Staphylococcus spp. Beta coefficients for covariates are not reported for clarity. *Interaction between bedding bacteria count and bedding type: main effects model reported.

difference in subclinical or clinical mastitis risk in the first $100 \mathrm{~d}$ of lactation in cows treated with the same 2 antibiotics (Arruda et al., 2013).

\section{Bedding Type Choice}

Only modest differences in quarter-level prevalence of ALL-IMI were observed in late-lactation cows using 4 common bedding materials evaluated: RMS (19.3\%), ON (22.7\%), NSA (23.9\%), and RSA (19.0\%). This finding is consistent with some studies that have failed to show bedding-associated differences in clinical mastitis incidence (Hogan et al., 1989) and SCC (Eckelkamp et al., 2016). However, other studies have identified associations between bedding type and bulk milk SCC (Ostrum et al., 2008; Rowbotham and Ruegg, 2015) and bacteria counts on teat skin (Rowbotham and Ruegg, 2016b). Rowbotham and Ruegg (2016a) found that the incidence rate of clinical mastitis (cases per 1,000 quarter days at risk) was numerically lower in primiparous cows using NSA (0.13) than in those using RSA (0.34) and RMS (incidence rate ratio = 0.31 ; type III $P$-value from Cox proportional hazards model $=0.06)$. In some cases, RMS has been associated with worse udder health (Ostrum et al., 2008). The perceived negative effects of RMS bedding on udder health has been mostly attributed to increased concentrations of coliform bacteria (Carroll and Jasper, 1978). As previously mentioned, only late-lactation cows were enrolled in our study, which may explain the very low prevalence of IMI caused by coliforms $(0.14 \%)$. This apparent resistance in late-lactation cows to coliform IMI may explain why RMS-exposed quarters had similar IMI prevalences to other bedding materials. Studies of early lactation cows may have identified meaningful differences in coliform IMI between bedding types. Interestingly, quarters exposed to RMS had a much lower prevalence $(2 \%)$ of SSLO than quarters exposed to NSA (7.1\%), ON (6.7\%), and RSA (7.3\%). This finding cannot be easily attributed to the SSLO count in RMS bedding, as it was numerically greater than most other bedding materials in both used and unused samples. The prevalence of Lactococcus spp. IMI was greater in quarters exposed to inorganic bedding (NSA: $3.3 \%$; RSA: $3.4 \%$ ) than those exposed to organic bedding (RMS: $0.2 \%$, ON: $0.3 \%$; OR $=11.02 ; 95 \%$ CI: 2.70-30.42). This finding is consistent with recent case reports of Lactococcus spp. outbreaks occurring in herds using inorganic bedding (Werner et al., 2014; Rodrigues et al., 2016; Eraclio et al., 2019).

\section{Bedding Bacteria Count Was Associated with Intramammary Infection in Late-Lactation Cows}

The findings from this study are generally consistent with the widely held belief that higher levels of bacteria in bedding material increase the risk of IMI. Three observational studies have shown positive associations be- 
tween BBC and clinical mastitis incidence (Carroll and Jasper, 1978; Thomas et al., 1983; Hogan et al., 1989). In each study, clinical mastitis incidence was only associated with counts of coliform or Klebsiella spp. in bedding. In this study, we were not able to identify associations between levels of coliform bacteria in bedding and coliform IMI, possibly due to the very low prevalence of IMI caused by gram-negative bacteria $(0.84 \%)$ and coliforms $(0.14 \%)$. A reason for this discrepancy between ours and previous studies may be that we were studying prevalence IMI in late-lactation cows, whereas previous studies reported on incidences of clinical mastitis events at any time during the lactation. Given that coliform IMI tend to be short-lived, cohort study designs would be more suitable than cross-sectional to investigate the potential effect of bedding-associated coliform bacteria on clinical mastitis incidence.

Our study is the first to demonstrate an association between counts of all bacteria, Staphylococcus spp., and SSLO in bedding and odds of subclinical IMI caused by these specific pathogen groups. However, in a crosssectional observational study such as this, such associations are not definitive proof of a causal relationship. For example, one could argue the causal relationship could be in the opposite direction, with high IMI prevalence increasing BBC. A study by Piessens et al. (2011) found that Staphylococcus chromogenes (the most common cause of IMI in our study) rarely established a reservoir in bedding material and was more often found in body sites of the cow, such as skin and the mammary gland. It is therefore possible that a higher prevalence of cows harboring this pathogen as an IMI could increase bacterial contamination of bedding material. This hypothesis is consistent with our findings, as there was only a positive association between Staphylococcus spp. count and NAS-IMI in used bedding samples and not in unused samples. It is possible that the association is bidirectional as some species of NAS may have an environmental reservoir, whereas other species of NAS may have their reservoir in body sites of the cow (Piessens et al., 2011). The positive association between SSLO counts and odds of SSLO-IMI is consistent with conventional understanding of these pathogens. Like NAS, molecular methods have implicated bedding material and other environmental sources as possible reservoirs for these pathogens (Eraclio et al., 2019). However, other studies have shown that some SSLO (especially Streptococcus uberis) can exhibit host adaptation and thus establish new IMI from intramammary reservoirs (Davies et al., 2016).

\section{Bedding Bacteria Count in Unused Bedding and Intramammary Infection Were Positively Associated in Most Bedding Material Types}

Total bacteria count in unused bedding was positively associated with odds of ALL-IMI $(\mathrm{OR}=1.08$, 95\% CI: 1.00-1.17), as were SSLO counts and odds

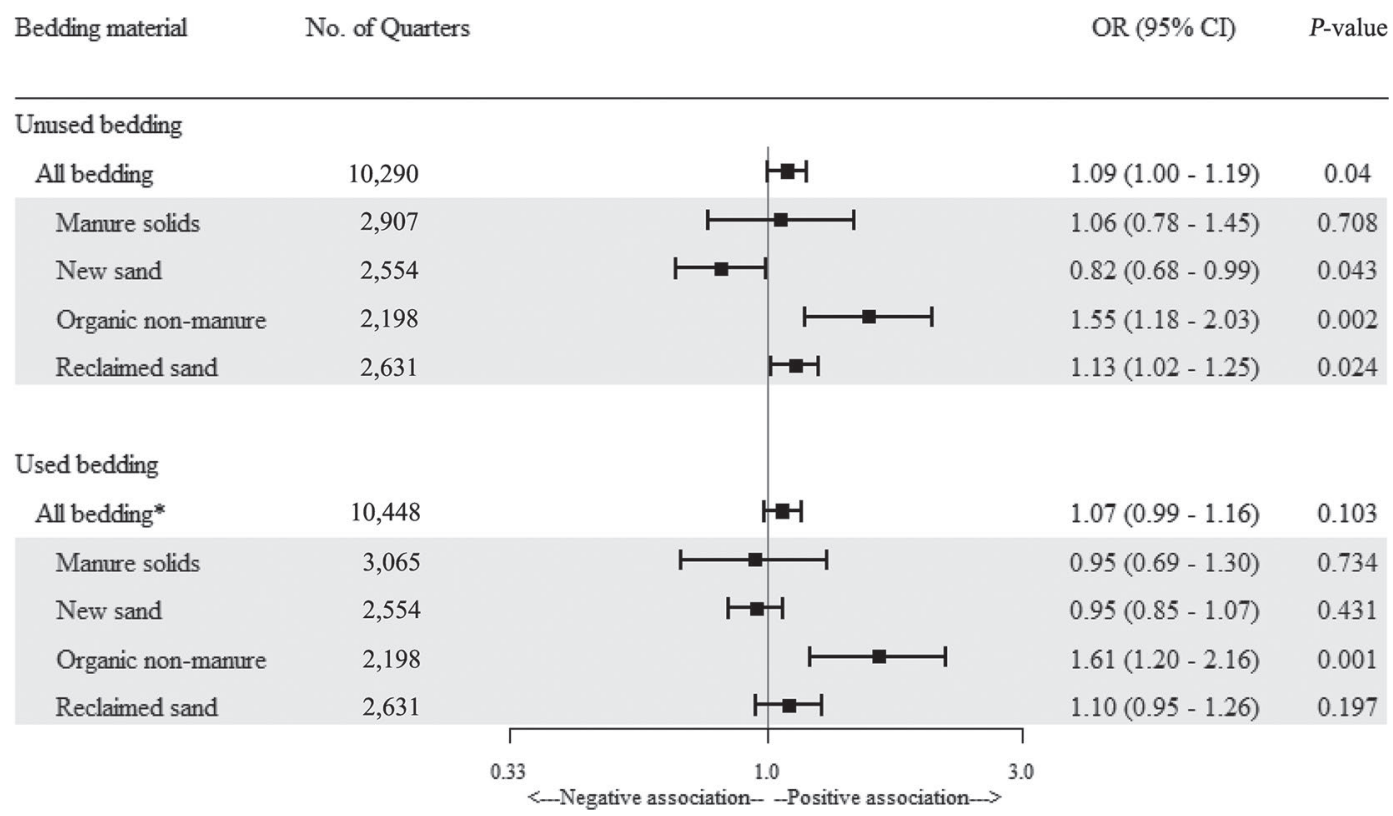

Figure 6. Streptococcus and Streptococcus-like organisms-IMI models. Odds ratio (OR) estimates and $95 \%$ CI from 10 multivariable logistic regression with mixed effects models investigating the association between bacteria levels in bedding and IMI caused by Streptococcus spp. and Streptococcus-like organisms. Beta coefficients for covariates are not reported for clarity. *Interaction between bedding bacteria count and bedding type: main effects model reported. 
of SSLO-IMI $(\mathrm{OR}=1.09,95 \%$ CI: $1.00-1.19)$. These associations were generally positive across all bedding types, except for a negative association between SSLO counts and SSLO-IMI in NSA exposed quarters $(\mathrm{OR}=$ 0.82; 95\% CI: 0.68-0.99). The absence of a positive association in NSA is not surprising, given that the SSLO in unused NSA bedding would not have originated from cows, which is in contrast to RSA (OR $=1.13 ; 95 \%$ CI: $1.02-1.25$ ), which would contain many SSLO from cow sources such as fecal material.

\section{Association Between Bacteria Count in Used Bedding and Intramammary Infection Varied by Bedding Material Type}

In contrast to unused bedding, we found that that the relationship between total bacteria count and odds of ALL-IMI in used bedding samples was inconsistent across bedding material types. Models evaluating the relationship between counts of all bacteria in bedding and ALL-IMI found positive associations in quarters exposed to RMS and ON, whereas no association or negative associations existed for quarters exposed to NSA and RSA (Figure 3). This finding is consistent with a study by Zdanowicz et al. (2004), which found that the correlation between $\mathrm{BBC}$ and teat skin bacteria count was higher in teats exposed to sawdust bedding than in sand bedding. However, that study did not directly investigate risk of IMI. There are several potential biological explanations for this effect modification. First, the physical characteristics of bedding materials, such as DM, could influence the efficiency of bacterial transmission onto teat skin surfaces. Second, this could be a result of bacterial profiles within each pathogen group differing by bedding material type. For example, counts of SSLO were generally higher in RMS than in ON bedding. However, the prevalence of SSLOIMI was higher in quarters exposed to $\mathrm{ON}(\mathrm{OR}=3.29)$ than those exposed to RMS. Furthermore, the relationship between bedding SSLO count and odds of SSLOIMI was positive in $\mathrm{ON}(\mathrm{OR}=1.61)$, but not in RMS $(\mathrm{OR}=0.95)$. Hypothetically, this could be due to a higher proportion of pathogenic SSLO species (such as Streptococcus dysgalactiae and Enterococcus spp. in this example) in ON than in RMS, thus causing a $1 \log _{10}$ unit increase in SSLO in ON to be more detrimental to udder health than in RMS. Evidence suggests that virulence varies significantly within an individual species of bacteria (Zadoks et al., 2011), so it is likely that enumerating bacteria at the genus level will, in some circumstances, lack the necessary precision to predict infection risk due to the heterogeneity of species within those groups. The development of new laboratory methods to better distinguish between pathogenic and nonpathogenic species would likely improve the utility of bedding culture in research studies and in mastitis control programs.

In quarters exposed to NSA bedding, we found that higher counts of all bacteria and of Staphylococcus spp. were associated with lower odds of ALL-IMI and NASIMI, respectively. Given that this negative association is at odds with basic biological concepts, we are suspicious that this finding may be spurious or biased. For example, bias could occur if culling risk was higher in herds with high BBC. However, very little is known about the bacteria communities in bedding, so our finding could potentially be valid. For example, it is plausible that when bacteria counts in NSA are high, they include high concentrations of nonpathogenic bacterial species that exhibit an antagonistic effect on pathogenic bacteria (Westphal et al., 2011). To our knowledge, the manipulation of bacterial communities in bedding material through inoculation has not been studied as a potential mastitis control strategy, but has been trialed in other farming systems (Corrêa et al., 2012). Regardless of the cause, the various associations between BBC and IMI among bedding materials suggests that there is unlikely to be a universal cut-point for bacterial counts that can be applied across all bedding systems.

\section{Utility of Bedding Bacteria Count Measurements as a Bedding Hygiene Monitoring Tool}

Bedding culture is an inexpensive test offered by several veterinary diagnostic laboratories in North America. However, bedding culture methods differ among laboratories and there is no consensus on which methods or reporting units should be used. Bacteria count as colony-forming units has been reported per milliliter/cubic centimeter (Bey et al., 2009), per gram (Zdanowicz et al., 2004), and per gram of DM (Hogan et al., 1989). In this study, we found that these measures were highly correlated and consequently delivered equivalent associations with IMI measures. Therefore, each of these measures is likely to be equally useful in research studies or for use in commercial dairy farms. However, variation in testing methods and units prevents meaningful comparisons of BBC among studies or laboratories that use different bedding culture protocols. We recommend that farmers testing bedding hygiene use a consistent approach (i.e., time of collection, collection technique, and laboratory) and monitor for increases in BBC. 


\section{Other Determinants of Intramammary Infection}

Quarters sampled during the winter period had a lower prevalence of IMI than in summer $(\mathrm{OR}=0.75$; 95\% CI: 0.66-0.84). This was due to a lower prevalence of IMI caused by NAS (OR $=0.64 ; 95 \%$ CI: $0.54-0.76)$. Other studies have identified summer as a risk factor for increased SCC in individual cows and bulk milk (Green et al., 2006; Olde Riekerink et al., 2007).

\section{Strengths and Limitations of This Study}

One considerable strength of this study is the large sample of herds and cows, which increases the generalizability of the findings and also increases statistical power, thus providing more precise effect estimates (i.e., relatively narrow 95\% CI). However, herds were selected by convenience into this study, which should be considered when generalizing results. Selection criteria included an existing relationship with the University of Minnesota or Zoetis, which may have biased the selection in favor of larger, well-managed herds. Nevertheless, this is the largest cross-sectional study of BBC and IMI conducted to date, and care was taken to randomly select herds from an eligible pool that included a broad cross-section of herds from all major US dairy regions, using a variety of housing and bedding management systems. Therefore, we believe this study has significant relevance to US dairy herds. Although the low IMI prevalence in this study indicates that selective DCT could be a method for producers to reduce antibiotic use, it should be stated that our study did not directly measure the impact of selective DCT on antibiotic use or health outcomes. Therefore, clinical trials are needed to further evaluate this on US farms. Furthermore, the relationship between bedding type, BBC, and IMI in late-lactation cows may not be generalizable to other subpopulations of cows (e.g., early or peak lactation). This deserves further study. The reliability of herdlevel estimates of prevalence (outlined in Table 2) are likely to vary among herds because the sample size for each herd was not adjusted to account for the number of cows. This is unlikely to be a source of error for quarter-level analysis, which accounts for almost all analysis reported.

As already mentioned, cross-sectional studies do not allow for causal inference. Furthermore, establishing exposure and outcome status from samples collected on the same day can introduce bias. We have assumed that the bacteria count measurements from a single bedding sample collected on the day of visit (the same day that milk samples were collected) was representative of the bacteria counts in the bedding that the quarters were actually exposed to during the period leading up to milk sampling. In our study, the used bedding age (time interval from adding unused bedding to sampling) was not standardized across farms and BBC has been shown to rapidly increase after it is added to stalls, especially during the first $24 \mathrm{~h}$ (Godden et al., 2008). However, we found that used bedding age was not strongly associated with $\mathrm{BBC}$ in our study $\left(+0.02 \log _{10}\right.$ cfu per day; 95\% CI: -0.01-0.04) and when included as a covariate to models predicting IMI, the effect estimates and associated confidence intervals did not change appreciably for BBC, suggesting that this unadjusted variability was not a significant source of bias. The median age of used bedding in our study was $2 \mathrm{~d}(\mathrm{IQR}=1-4)$.

Freezing bedding samples could have also introduced measurement error. A recent experiment showed that freezing sand and RMS bedding for 1, 2, or 3 wk reduced counts of gram-negative and coliform bacteria, but not other species (Homerosky and Hogan, 2015). It is therefore possible that the counts of gram-negative and coliform bacteria shown in Table 3 may be underestimated. However, given that no associations were made between counts of these species and IMI, it is unlikely that this measurement error has led to significant bias in our study.

Another potential source of measurement error is the upper detection limit of BBC. As reported, the proportion of used bedding samples with counts of SSLO at the upper detection limit $\left(6.80 \log _{10} \mathrm{cfu} / \mathrm{mL}\right)$ was RMS (28.6\%), NSA (29.7\%), ON (18.8\%), and RSA (7.7\%). Therefore, the extremes of SSLO counts (our explanatory variable) were not fully represented in our regression models, which could have biased the association between BBC and IMI.

\section{Future Research}

Cross-sectional studies similar to this that enroll cows from earlier stages of lactation would allow for additional insights into the relationship between bedding hygiene and the development of mastitis during lactation. A small number of observational studies (including this one) have demonstrated an association between BBC and IMI. However, no studies have shown that reducing $\mathrm{BBC}$ improves udder health. Therefore, research is needed to identify best management practices and the cost effectiveness of interventions designed to reduce BBC. We plan to use the data set from this study to investigate the relationship between bedding management practices, bedding characteristics (e.g., moisture and OM concentrations), and bedding bacteria counts. 


\section{CONCLUSIONS}

In a cross-sectional study of late-lactation cows from 78 US dairy herds, the prevalence of ALL-IMI was $21.05 \%$ of quarters and $50.4 \%$ of cows, respectively. Most IMI were caused by NAS and SSLO, with very few quarters infected with coliform bacteria. We found that $\mathrm{BBC}$ was positively associated with odds of IMI in general. The association between BBC in unused bedding and IMI was mostly consistent across all 4 common bedding material types. In contrast, the association between counts of bacteria in used bedding and IMI varied by bedding material type. Only modest differences in IMI prevalence were observed between the 4 common bedding material types (RMS, NSA, $\mathrm{ON}$, and RSA). These results indicate that none of the bedding materials evaluated in this study were superior to another relative to the odds of IMI in late lactation. Further research is necessary to investigate the effects and potential benefits of reducing BBC on udder health.

\section{ACKNOWLEDGMENTS}

We thank the Zoetis Quality Milk Specialist and Dairy Technical Services teams (Julio Alcantar, Michele Barrett, Karthryn Browning, Ruben Gonzalez, Samuel Herrera, Bernard Kwaku, Shawn Hull, Doris Ledwith, John Lee, Francisco Rivas, and Bill Sullivan), who conducted the fieldwork in herds located outside of Minnesota. We also thank doctor of veterinary medicine students from the University of Minnesota, Samuel Basquin, Edouard Cotten, Wanda Weber, and Aaron Rendahl. M. Boyle is an employee of Zoetis. He was involved in the study design and conceptualization with review of the manuscript. He was not involved with any analyses of data. All others have no competing interests to declare. S. M. Rowe was involved in fieldwork, laboratory work, data management, analysis, and manuscript preparation. S. M. Godden was involved in supervision, study conceptualization, fieldwork, and manuscript editing. E. Royster was involved in study conceptualization and manuscript editing. B. A. Crooker was involved in laboratory work and manuscript editing. J. Timmerman was involved in laboratory work and manuscript editing. M. Boyle was involved in study conceptualization, fieldwork coordination, and manuscript editing. This study was funded by Zoetis (Parsippany, NJ).

\section{REFERENCES}

Arruda, A. G., S. Godden, P. Rapnicki, P. Gorden, L. Timms, S. S. Aly, T. W. Lehenbauer, and J. Champagne. 2013. Randomized noninferiority clinical trial evaluating 3 commercial dry cow mastitis preparations: I. Quarter-level outcomes. J. Dairy Sci. 96:4419-4435.

Bey, R., S. Godden, and B. Kuechle. 2009. Effect of bedding conditioners on bacteria counts and $\mathrm{pH}$ in shavings, digested manure solids and recycled sand bedding. Bov. Pract. 43:56-65.

Bradley, A. J., S. De Vliegher, M. J. Green, P. Larrosa, B. Payne, E. S. van de Leemput, O. Samson, D. Valckenier, T. Van Werven, H. W. Waldeck, V. White, and L. Goby. 2015. An investigation of the dynamics of intramammary infections acquired during the dry period on European dairy farms. J. Dairy Sci. 98:6029-6047.

Braem, G., S. De Vliegher, B. Verbist, M. Heyndrickx, F. Leroy, and L. De Vuyst. 2012. Culture-independent exploration of the teat apex microbiota of dairy cows reveals a wide bacterial species diversity. Vet. Microbiol. 157:383-390.

Cameron, M., S. L. McKenna, K. A. MacDonald, I. R. Dohoo, J. P. Roy, and G. P. Keefe. 2014. Evaluation of selective dry cow treatment following on-farm culture: Risk of postcalving intramammary infection and clinical mastitis in the subsequent lactation. J. Dairy Sci. 97:270-284.

Carroll, E. J., and D. Jasper. 1978. Distribution of Enterobacteriaceae in recycled manure bedding on california dairies. J. Dairy Sci. 61:1498-1508.

Corrêa, E. K., R. R. Ulguim, L. B. Corrêa, D. D. Castilhos, I. Bianchi, C. Gil-Turnes, and T. Lucia Jr.. 2012. Addition of Bacillus sp. inoculums in bedding for swine on a pilot scale: Effect on microbial population and bedding temperature. Bioresour. Technol. 121:127-130.

Davies, P. L., J. Leigh, A. Bradley, S. Archer, R. Emes, and M. J. Green. 2016. Molecular epidemiology of Streptococcus uberis clinical mastitis in dairy herds: Strain heterogeneity and transmission. J. Clin. Microbiol. 54:68-74.

Dohoo, I. R., J. Smith, S. Andersen, D. F. Kelton, and S. Godden. 2011. Diagnosing intramammary infections: Evaluation of definitions based on a single milk sample. J. Dairy Sci. 94:250-261.

Eckelkamp, E., J. Taraba, K. Akers, R. Harmon, and J. Bewley. 2016. Sand bedded freestall and compost bedded pack effects on cow hygiene, locomotion, and mastitis indicators. Livest. Sci. 190:48-57.

Eraclio, G., G. Ricci, P. Moroni, C. Santisteban, C. Plumed-Ferrer, J. Bennett, and M. G. Fortina. 2019. Sand bedding as a reservoir for Lactococcus garvieae dissemination in dairy farms. Can. J. Microbiol. 65:84-89.

Godden, S., R. Bey, K. Lorch, R. Farnsworth, and P. Rapnicki. 2008. Ability of organic and inorganic bedding materials to promote growth of environmental bacteria. J. Dairy Sci. 91:151-159.

Green, M., A. Bradley, H. Newton, and W. Browne. 2006. Seasonal variation of bulk milk somatic cell counts in UK dairy herds: Investigations of the summer rise. Prev. Vet. Med. 74:293-308.

Green, M., L. Green, G. Medley, Y. Schukken, and A. Bradley. 2002. Influence of dry period bacterial intramammary infection on clinical mastitis in dairy cows. J. Dairy Sci. 85:2589-2599.

Haine, D., I. Dohoo, and S. Dufour. 2018. Selection and misclassification biases in longitudinal studies. Front. Vet. Sci. 5:99.

Hogan, J. S., V. Bogacz, L. Thompson, S. Romig, P. Schoenberger, W. Weiss, and K. Smith. 1999. Bacterial counts associated with sawdust and recycled manure bedding treated with commercial conditioners. J. Dairy Sci. 82:1690-1695.

Hogan, J. S., and K. Smith. 1997. Bacteria counts in sawdust bedding. J. Dairy Sci. 80:1600-1605.

Hogan, J. S., K. Smith, K. Hoblet, D. Todhunter, P. Schoenberger, W. Hueston, D. Pritchard, G. Bowman, L. E. Heider, and B. Brockett. 1989. Bacterial counts in bedding materials used on nine commercial dairies. J. Dairy Sci. 72:250-258.

Homerosky, E., and J. Hogan. 2015. Effects of freezing on bacterial counts in bovine bedding materials. Natl. Mastitis Counc. Mtg. Proc. Memphis, TN. Natl. Mastitis Counc. Inc., Verona, WI.

Johnson, A. P., S. M. Godden, E. Royster, S. Zuidhof, B. Miller, and J. Sorg. 2016. Randomized noninferiority study evaluating the efficacy of 2 commercial dry cow mastitis formulations. J. Dairy Sci. 99:593-607.

Lass-Flörl, C., and A. Mayr. 2007. Human protothecosis. Clin. Microbiol. Rev. 20:230-242. 
Lubin, J. H., J. S. Colt, D. Camann, S. Davis, J. R. Cerhan, R. K. Severson, L. Bernstein, and P. Hartge. 2004. Epidemiologic evaluation of measurement data in the presence of detection limits. Environ. Health Perspect. 112:1691-1696.

NAHMS. 2014. Milk Quality, Milking Procedures, and Mastitis in the United States. USDA-APHIS-VS-CEAH-National Animal Health Monitoring System, Fort Collins, CO.

Natzke, R. P., and B. J. LeClair. 1976. Coliform contaminated bedding and new infections. J. Dairy Sci. 59:2152-2154.

NMC. 2017. Laboratory Handbook on Bovine Mastitis. NMC, Madison, WI.

Olde Riekerink, R. G., H. Barkema, and H. Stryhn. 2007. The effect of season on somatic cell count and the incidence of clinical mastitis. J. Dairy Sci. 90:1704-1715.

Ostrum, P. G., M. J. Thomas, and R. N. Zadoks. 2008. Dried manure solids for freestall bedding: Experiences from a Northeast dairy. Proc. Annu. Meet. 47:149-156.

Pantoja, J. C., C. Hulland, and P. L. Ruegg. 2009. Dynamics of somatic cell counts and intramammary infections across the dry period. Prev. Vet. Med. 90:43-54.

Patel, K., S. Godden, E. Royster, J. Timmerman, B. Crooker, and N. McDonald. 2017. Pilot Study: Impact of using a culture-guided selective dry cow therapy program targeting quarter-level treatment on udder health and antibiotic use. Bov. Pract. 51:48-57.

Piessens, V., E. Van Coillie, B. Verbist, K. Supré, G. Braem, A. Van Nuffel, L. De Vuyst, M. Heyndrickx, and S. De Vliegher. 2011. Distribution of coagulase-negative Staphylococcus species from milk and environment of dairy cows differs between herds. J. Dairy Sci. 94:2933-2944.

Pinedo, P. J., C. Fleming, and C. Risco. 2012. Events occurring during the previous lactation, the dry period, and peripartum as risk factors for early lactation mastitis in cows receiving 2 different intramammary dry cow therapies. J. Dairy Sci. 95:7015-7026.

Pol, M., and P. Ruegg. 2007. Treatment practices and quantification of antimicrobial drug usage in conventional and organic dairy farms in Wisconsin. J. Dairy Sci. 90:249-261.

Proietto, R. L., L. Hinckley, L. Fox, and S. Andrew. 2013. Evaluation of a clay-based acidic bedding conditioner for dairy cattle bedding. J. Dairy Sci. 96:1044-1053.

R Core Team. 2018. R: A Language and Environment for Statistical Computing. R Foundation for Statistical Computing, Vienna, Austria.

Redding, L. E., J. Bender, and L. Baker. 2019. Quantification of antibiotic use on dairy farms in Pennsylvania. J. Dairy Sci. 102:14941507.

Ricchi, M., M. Goretti, E. Branda, G. Cammi, C. Garbarino, B. Turchetti, P. Moroni, N. Arrigoni, and P. Buzzini. 2010. Molecular characterization of Prototheca strains isolated from Italian dairy herds. J. Dairy Sci. 93:4625-4631.

Rodrigues, M. X., S. Lima, C. Higgins, S. Canniatti-Brazaca, and R. Bicalho. 2016. The Lactococcus genus as a potential emerging mastitis pathogen group: A report on an outbreak investigation. J. Dairy Sci. 99:9864-9874.

Rowbotham, R. F., and P. Ruegg. 2015. Association of bedding types with management practices and indicators of milk quality on larger Wisconsin dairy farms. J. Dairy Sci. 98:7865-7885.

Rowbotham, R. F., and P. Ruegg. 2016a. Associations of selected bedding types with incidence rates of subclinical and clinical mastitis in primiparous Holstein dairy cows. J. Dairy Sci. 99:4707-4717.
Rowbotham, R. F., and P. Ruegg. 2016b. Bacterial counts on teat skin and in new sand, recycled sand, and recycled manure solids used as bedding in freestalls. J. Dairy Sci. 99:6594-6608.

Sargeant, J. M., A. M. O'Connor, I. Dohoo, H. Erb, M. Cevallos, M. Egger, A. K. Ersbøll, S. Martin, L. R. Nielsen, and D. Pearl. 2016. Methods and processes of developing the Strengthening the Reporting of Observational Studies in Epidemiology-Veterinary (STROBE-Vet) statement. J. Vet. Intern. Med. 30:1887-1895.

Smith, K. L., D. Todhunter, and P. Schoenberger. 1985. Environmental pathogens and intramammary infection during the dry period. J. Dairy Sci. 68:402-417.

Thomas, C., D. Jasper, M. Rollins, R. Bushnell, and E. Carroll. 1983. Enterobacteriaceae bedding populations, rainfall and mastitis on a California dairy. Prev. Vet. Med. 1:227-242.

Vanderhaeghen, W., S. Piepers, F. Leroy, E. Van Coillie, F. Haesebrouck, and S. De Vliegher. 2014. Invited review: Effect, persistence, and virulence of coagulase-negative Staphylococcus species associated with ruminant udder health. J. Dairy Sci. 97:5275-5293.

Vasquez, A., D. Nydam, C. Foditsch, M. Wieland, R. Lynch, S. Eicker, and P. Virkler. 2018. Use of a culture-independent on-farm algorithm to guide the use of selective dry-cow antibiotic therapy. J. Dairy Sci. 101:5345-5361.

Verbist, B., V. Piessens, A. Van Nuffel, L. De Vuyst, M. Heyndrickx, L. Herman, E. Van Coillie, and S. De Vliegher. 2011. Sources other than unused sawdust can introduce Klebsiella pneumoniae into dairy herds. J. Dairy Sci. 94:2832-2839.

Werner, B., P. Moroni, G. Gioia, L. Lavín-Alconero, A. Yousaf, M. Charter, B. M. Carter, J. Bennett, D. Nydam, and F. Welcome. 2014. Genotypic and phenotypic identification of environmental streptococci and association of Lactococcus lactis ssp. lactis with intramammary infections among different dairy farms. J. Dairy Sci. 97:6964-6969.

Westphal, A., M. L. Williams, F. Baysal-Gurel, J. T. LeJeune, and B. B. M. Gardener. 2011. General suppression of Escherichia coli O157: H7 in sand-based dairy livestock bedding. Appl. Environ. Microbiol. 77:2113-2121.

Wyder, A. B., R. Boss, J. Naskova, T. Kaufmann, A. Steiner, and H. U. Graber. 2011. Streptococcus spp. and related bacteria: Their identification and their pathogenic potential for chronic mastitis-a molecular approach. Res. Vet. Sci. 91:349-357.

Zadoks, R. N., J. R. Middleton, S. McDougall, J. Katholm, and Y. H. Schukken. 2011. Molecular epidemiology of mastitis pathogens of dairy cattle and comparative relevance to humans. J. Mammary Gland Biol. Neoplasia 16:357-372.

Zdanowicz, M., J. Shelford, C. Tucker, D. Weary, and M. Von Keyserlingk. 2004. Bacterial populations on teat ends of dairy cows housed in free stalls and bedded with either sand or sawdust. J. Dairy Sci. 87:1694-1701.

\section{ORCIDS}

S. M. Rowe @ https://orcid.org/0000-0001-8336-6523

S. M. Godden () https://orcid.org/0000-0002-4438-0039

E. Royster (1) https://orcid.org/0000-0002-8298-5581

B. A. Crooker $\odot$ https://orcid.org/0000-0002-8433-9946 